\title{
Mixing of Incompatible Materials in Waste Tanks Technical Basis Document
}

\section{K. R. Sandgren}

CH2M HILL Hanford Group, Inc.

Richland, WA 99352

U.S. Department of Energy Contract DE-AC27-99RL14047

$\begin{array}{lll}\text { EDT/ECN: } & 723852 & \text { UC: N/A } \\ \text { Cost Center: } 7 \mathrm{G} 530 & \text { Charge Code: } 502644 \\ \text { B\&R Code: } & \text { N/A } & \text { Total Pages: } 60\end{array}$

Key Words:

Incompatible material, sulfuric acid, carbon dioxide, DST, SST, bulk chemical addition, accident, consequence, technical basis document

\section{Abstract:}

This document presents onsite radiological, onsite toxicological, and offsite toxicological consequences, risk binning, and control decision results for the mixing of incompatible materials in waste tanks representative accident. Revision 4 updates the analysis to consider bulk chemical additions to SSTs.

TRADEMARK DISCLAIMER. Reference herein to any specific commercial product, process, or service by trade name, trademark, manufacturer, or otherwise, does not necessarily constitute or imply its endorsement, recommendation, or favoring by the United States Government or any agency thereof or its contractors or subcontractors.

Printed in the United States of America. To obtain copies of this document, contact: Document Control Services, P.O. Box 950, Mailstop H6-08, Richland WA 99352, Phone (509) 372-2420; Fax (509) 376-4989.

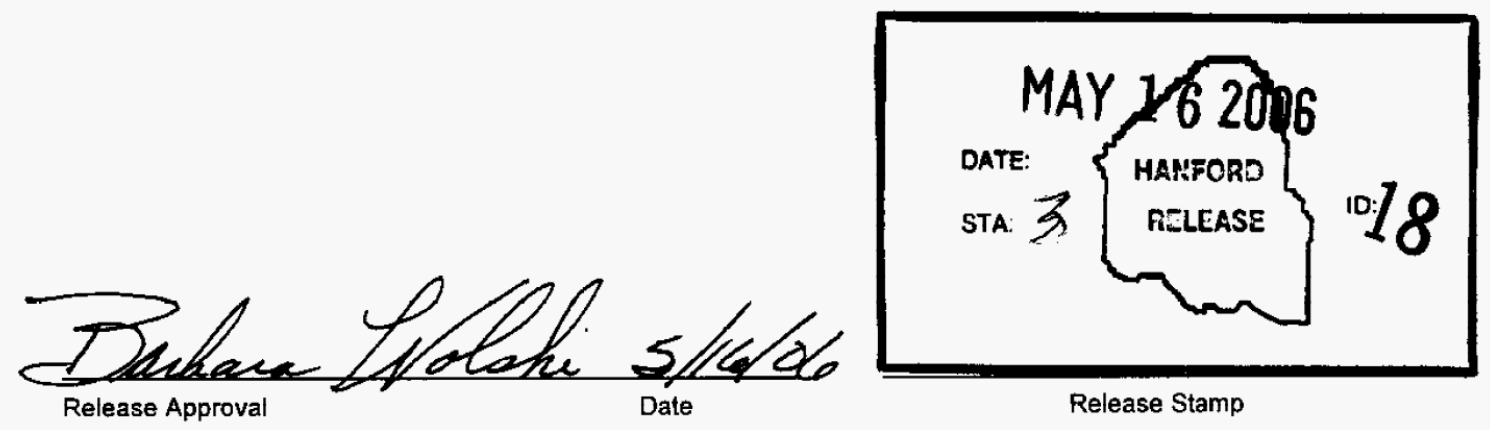

Approved For Public Release 


\section{CONTENTS}

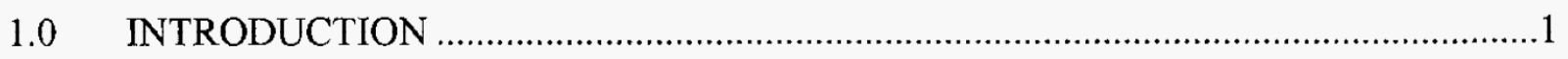

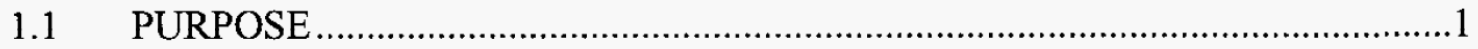

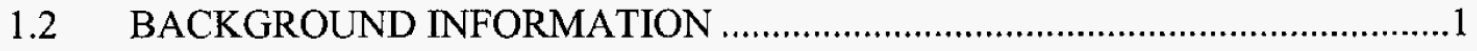

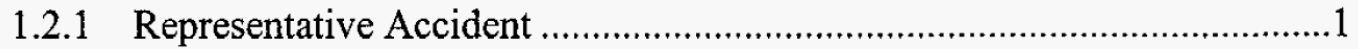

1.2.2 Bounding Offsite Accident ................................................................

1.2.3 Associated Hazardous Conditions ….....................................................

1.3 RISK BINNING METHODOLOGY ............................................................

$2.0 \quad$ RISK BINNING RESULTS ...............................................................................

2.1 MIXING OF INCOMPATIBLE MATERIALS REPRESENTATIVE

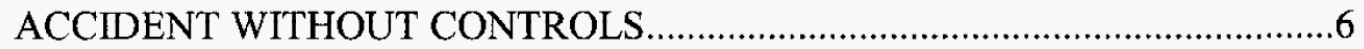

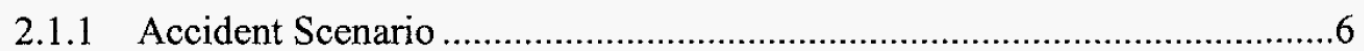

2.1.2 Frequency Determination...............................................................6

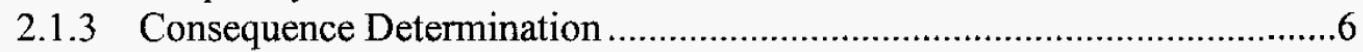

2.2 MIXING OF INCOMPATIBLE MATERIALS ASSOCIATED

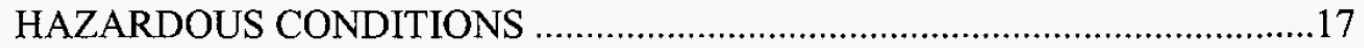

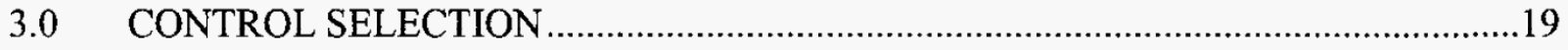

3.1 PROPOSED CONTROLS FOR THE MIXING OF INCOMPATIBLE MATERIALS REPRESENTATIVE ACCIDENT ............................................19

3.2 SELECTED CONTROL FOR THE MIXING OF INCOMPATIBLE MATERIALS REPRESENTATIVE ACCIDENT ............................................20

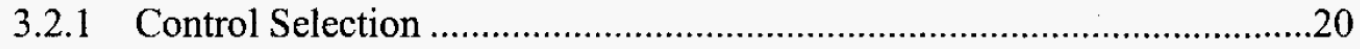

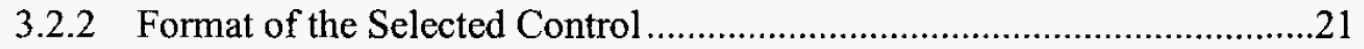

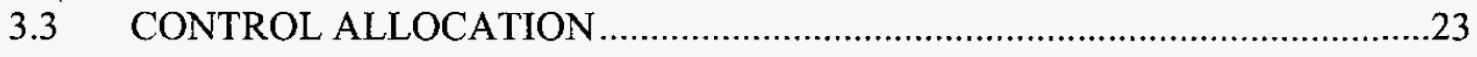

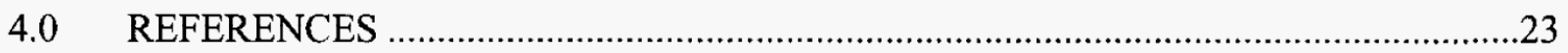


RPP-12646 REV 4

\section{APPENDICES}

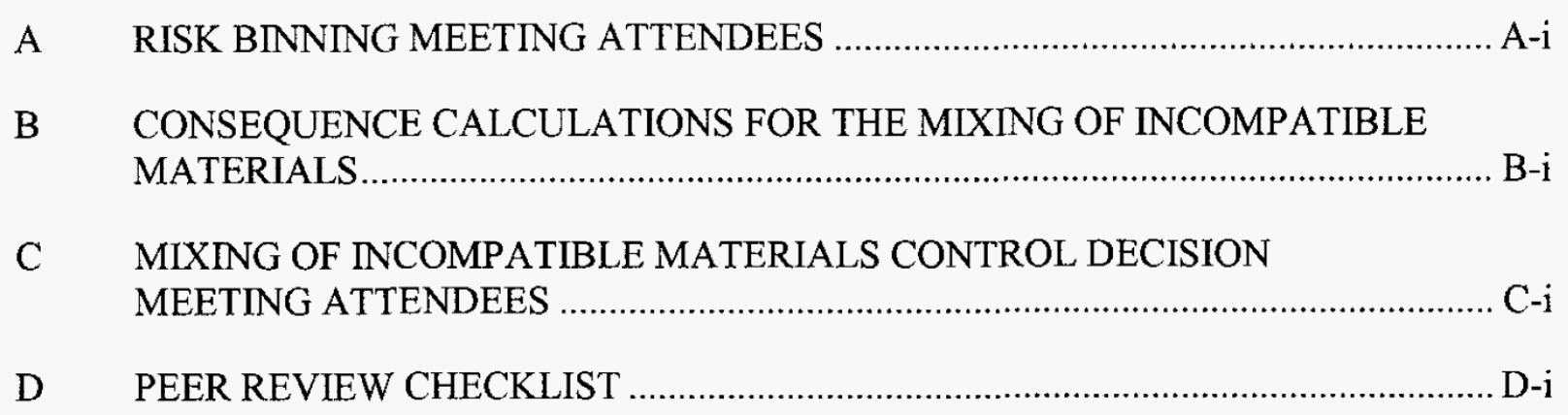

\section{LIST OF TABLES}

Table 1-1. Offsite (Toxicological Only) Risk Bins. ......................................................... 4

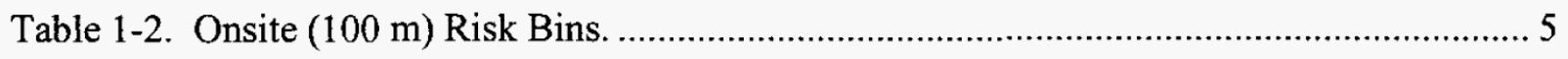

Table 1-3. Environmental Consequence Categories...................................................... 5

Table 2-1. Summary of Final Risk Binning Results for Represented Conditions..................... 9

Table 2-2. Qualitative Evaluation of Analysis Assumptions for Representative Accident ......... 10

Table 2-3. Summary of Onsite Radiological Consequences for the Mixing of Incompatible Materials Without Controls.......................................................... 16

Table 2-4. Summary of Toxicological Consequences for the Mixing of Incompatible Materials Without Controls.............................................................................. 16

Table 2-5. Summary of Final Risk Binning Results for Associated Conditions. ...................... 18

Table 3-1. Summary of Technical Safety Requirement Controls for Mixing of Incompatible Material. 


\section{RPP-12646 REV 4}

\section{LIST OF TERMS}

$\begin{array}{ll}\text { AC } & \text { administrative control } \\ \text { ARF } & \text { airborne release fraction } \\ \text { double-contained receiver tank } \\ \text { DCRT } & \text { documented safety analysis } \\ \text { DSA } & \text { double-shell tank } \\ \text { DST } & \text { emergency response planning guideline } \\ \text { ERPG } & \text { high-efficiency particulate air (filter) } \\ \text { HEPA } & \text { Plutonium Finishing Plant } \\ \text { PFP } & \text { safety management program } \\ \text { SMP } & \text { sum of fractions } \\ \text { SOF } & \text { structures, systems, and components } \\ \text { SSC } & \text { single-shell tank } \\ \text { SST } & \text { Temporary Emergency Exposure Limit } \\ \text { TEEL } & \text { technical safety requirement } \\ \text { TSR } & \text { Technical Working Group } \\ \text { TWG } & \text { unit-liter dose }\end{array}$


RPP-12646 REV 4

This page intentionally left blank. 
RPP-12646 REV 4

\subsection{INTRODUCTION}

\subsection{PURPOSE}

This technical basis document was developed to support the tank farms documented safety analysis (DSA) and describes the risk binning process, the technical basis for assigning risk bins, and the controls selected for the mixing of incompatible materials representative accident and associated represented hazardous conditions. The purpose of the risk binning process is to determine the need for safety-significant structures, systems, and components (SSC) and/or technical safety requirement (TSR)-level controls for a given representative accident or represented hazardous conditions based on an evaluation of the frequency and consequence. Note that the risk binning process is not applied to facility workers, because all facility worker hazardous conditions are considered for safety-significant SSCs and/or TSR-level controls. (See RPP-14286, Facility Worker Technical Basis Document.) Determination of the need for safety-class SSCs was performed in accordance with DOE-STD-3009-94, Preparation Guide for U.S. Department of Energy Nonreactor Nuclear Facility Documented Safety Analyses, as described below.

\subsection{BACKGROUND INFORMATION}

\subsubsection{Representative Accident}

Routine tank farm operations include a number of material transfer activities such as waste transfers between tanks, incoming waste transfers from non-tank farm facilities (e.g., Plutonium Finishing Plant [PFP], 222-S Laboratory, T Plant), and bulk chemical additions to double-shell tanks (DST) and 100-series single-shell tanks (SST) for corrosion control or waste dissolution. When considering the related hazards within tank farms, it was postulated that the mixing of incompatible material in a waste tank could result in a chemical reaction that produces aerosols and enough internal pressure to expel headspace gases, vapors, and aerosolized waste.

Incompatible materials that could potentially be transferred to tank farm facilities were studied to determine a bounding case. The scenarios that were considered were:

Scenario 1. Addition of an incompatible material due to a waste transfer from an internal or external source:

Case A. Misrouting or transfer of incompatible tank waste

Case B. Incompatible waste addition from external source.

Scenario 2. Inadvertent addition of an incompatible chemical due to a vendor or paperwork error when making a chemical addition to a tank:

Case A. Addition of excess base to a waste tank

Case B. Addition of acid to a waste tank waste.

As the tank wastes are similar, reactions due to a transfer from one tank to another will not result in a significant release according to Reynolds (2001), "Potential for Tank Farm Systems to Give 


\section{RPP-12646 REV 4}

Off Toxic Chemicals or Pressurizing Due to Chemical Incompatibility." Reynolds (2001) was included as an appendix to RPP-9689, Offsite Radiological Consequence Calculation for the Bounding Mixing of Incompatible Materials Accident. Therefore, Case A of Scenario 1 was discarded as a potential bounding case.

The majority of waste that is generated externally to tank farms would come from the PFP, the 222-S Laboratory, and T Plant. Each of these facilities utilizes practices that ensure the final facility waste solution is not transferred to incompatible tank waste. In addition, the transfer lines are not compatible with strong acids (the most common incompatible material) and would fail before large volumes could be transferred. Therefore, Scenario 1, Case B was discarded as the bounding case.

Inadvertent addition of chemicals was then examined. The addition of excess base to tank waste was examined for the potential to react and produce ammonia. Substantial amounts of ammonia are dissolved or trapped in some tank wastes. Ammonia is produced by the decomposition of nitrogen-containing compounds that were added to process solutions that eventually ended up as waste. Amine chelating agents such as ethylenediaminetetraacetic acid are among the chief sources. There is some potential for the ammonia in these wastes to be released into the vapor space of tanks and vented to the atmosphere.

The solubility of ammonia increases with decreasing $\mathrm{pH}$ due to an increasing fraction of the dissolved ammonia existing as the ammonium ion. As $\mathrm{pH}$ is raised, the ammonium ion is converted to the neutral, molecular ammonia solute (aqueous $\mathrm{NH}_{3}$ ). The neutral aqueous ammonia desorbs to become gaseous or vapor phase ammonia. The main reactions are as follows:

$$
\begin{aligned}
& \mathrm{NH}_{4}^{+}+\mathrm{OH}^{-} \rightleftharpoons \mathrm{NH}_{3 \text { (aqueous) }}+\mathrm{H}_{2} \mathrm{O} \\
& \mathrm{NH}_{3 \text { (aqueous) }} \rightleftharpoons \mathrm{NH}_{3 \text { (vapor) }} .
\end{aligned}
$$

The potential exists for strong bases to be accidentally added to waste tanks in amounts that may reduce the solubility of ammonia. A series of calculations were performed to predict the solubility of ammonia in a simulated waste and the effect of adding various amounts of $100 \%$ sodium hydroxide to the worst-case tank waste. It was found that a large amount of sodium hydroxide (slightly over 4 moles/L of waste) must be added to reach the ammonia saturation point before any ammonia is released by the reaction. An estimate of the bounding ammonia release was calculated in WHC-SD-WM-CN-074, Chemical Reaction in a DCRT Leading to a Toxic Release. It was shown that the consequences of an ammonia release are well within conservative guidelines. Therefore, Scenario 2, Case A, was not selected as the representative case.

Since direct chemical additions can be made to the waste tanks, an accident was postulated in which bulk delivery of an unexpected chemical is made to a waste tank (e.g., instead of the caustic addition expected, the delivery truck contains an acid). Since the delivery was assumed to be from a large tanker truck, only common chemicals that are routinely shipped in bulk quantities were considered. Common industrial acids were evaluated for their potential to react with tank waste resulting in gas or vapor generation. The reaction of strong acids with carbonate waste was found to produce large quantities of carbon dioxide. The reaction of acids with nitrite 
waste was also considered. It was postulated that the addition of acid could result in the release of nitrogen or an oxide of nitrogen. At basic conditions the production of one mole of nitrogen per two moles of $\mathrm{H}^{+}$ions is possible, while at acidic conditions the production of one mole of nitrogen oxide per mole of $\mathrm{H}^{+}$ions is possible. Thus, the reaction of acid with carbonate would be competing with the reaction of acid and nitrite as well as the neutralization reaction of acid with hydroxide. Experiments on the dissolution of waste with excess acid have been performed (Herting 2003, Final Report for Tank 241-C-106 Sludge Dissolution, Phase II). Waste from both SST 241-C-106 and DST 241-AY-102 was contacted with acid. DST 241-AY-102 waste contains similar quantities of nitrite and carbonate while SST 241-C-106 waste contains nearly 40 times more carbonate than nitrite. Samples of the gases generated by the experiments were collected and analyzed. It was found that carbon dioxide was nearly the only gas produced with traces of hydrogen also being detected at concentrations three to four orders of magnitude less than the carbon dioxide (oxides of nitrogen were not detected). Since the production of carbon dioxide was shown to be the dominant factor, the production of carbon dioxide was selected as the representative accident. The addition of concentrated sulfuric acid to the tank waste was identified as the bounding case and is presented here.

\subsubsection{Bounding Offsite Accident}

The mixing of incompatible materials accident is the bounding, low-energy atmospheric vapor/gas/aerosol release event, and has been quantitatively analyzed for comparison to the DOE-STD-3009-94, Appendix A, "Evaluation Guideline," of $25 \mathrm{rem}$. The bounding quantitative analysis for the mixing of incompatible materials accident is documented in RPP-9689, and shows that offsite radiological consequences are less than 1 rem. Therefore, no safety-class equipment or TSR-level controls need to be considered for offsite radiological exposures for any of the low-energy atmospheric vapor/gas/aerosol release events. It is important to note that DOE-STD-3009-94 does not provide any other evaluation guidelines (i.e., evaluation guidelines are not provided for offsite toxicological, onsite radiological, and onsite toxicological exposures). These exposures were evaluated for the representative accident and associated hazardous conditions in accordance with the risk binning process described in Section 1.3.

\subsubsection{Associated Hazardous Conditions}

In addition to the hazardous condition that defines the representative accident, the current hazard evaluation database lists a number of hazardous conditions that are represented by the mixing of incompatible materials accident. The hazardous conditions typically involve chemical reactions caused by mixing incompatible materials and are postulated to occur in the various tanks (DSTs, SSTs, and double-contained receiver tanks [DCRT]). Also grouped under the mixing of incompatible materials representative accident are various types of conditions that result in the release of ammonia vapors. The ammonia release conditions were assigned to the mixing of incompatible materials accident because they most closely resembled the ammonia releases that were due to the inadvertent addition of excess base. Some type of waste disturbing activity is generally the cause of these ammonia release events. 


\subsection{RISK BINNING METHODOLOGY}

Direction on risk binning was provided by the U.S. Department of Energy, Office of River Protection (Klein and Schepens, 2003, "Replacement of Previous Guidance Provided by RL and ORP"). Risk binning begins with a qualitative evaluation of the frequency and consequence of the representative accident. Frequency is qualitatively estimated as "anticipated," "unlikely," "extremely unlikely," or "beyond extremely unlikely." Consequences are evaluated for the following receptors and exposures: offsite toxicological, onsite radiological, and onsite toxicological. These consequences are assigned to one of three categories: high, moderate, or low. Based on the frequency and consequence, risk bins (ranging from I to IV) are assigned. Tables 1-1 and 1-2 show the criteria for assigning the frequency and consequence levels, and the risk bins, which are assigned to the various combinations of frequency and consequence. After the risk binning process is completed for the representative accident, the process is then repeated for the represented hazardous conditions associated with the representative accident.

In accordance with the control selection guidelines in Klein and Schepens (2003), Risk Bin I events require safety-significant SSCs or TSRs, and Risk Bin II events must consider safety-significant SSCs and TSRs. Risk Bin III events are generally protected by the safety management programs (SMP), and Risk Bin IV events do not require additional measures. Initial DSA development was largely completed before Klein and Schepens 2003 was issued and more conservative control selection guidelines were used. During DSA development, safety SSCs and/or TSR-level controls were required for accidents or hazardous conditions that are assigned to Risk Bins I or II, and are considered for accidents or hazardous conditions that are assigned to Risk Bin III. For accidents or hazardous conditions assigned to Risk Bin IV, safety SSCs and TSR-level controls were not expected. SMPs were acceptable for addressing the residual risk posed by Risk Bin IV conditions.

Table 1-1. Offsite (Toxicological Only) Risk Bins.

\begin{tabular}{|l|c|c|c|c|}
\hline \multirow{2}{*}{$\begin{array}{c}\text { Consequence category } \\
\text { (toxicological only') }\end{array}$} & $\begin{array}{c}|c| \\
\text { Beyond extremely } \\
\text { unlikely }\end{array}$ & $\begin{array}{c}<0^{-6} / \mathbf{y r} \\
\mathbf{1 0} \text { to } 10^{-6} / \mathbf{y r} \\
\text { Extremely } \\
\text { unlikely }\end{array}$ & $\begin{array}{c}10^{-2} \text { to } 10^{-4} / \mathbf{y r} \\
\text { Unlikely }\end{array}$ & $\begin{array}{c}10^{-1} \text { to } 10^{-2} / \mathbf{y r} \\
\text { Anticipated }\end{array}$ \\
\hline $\begin{array}{l}\text { >ERPG-2 / TEEL-2 } \\
\text { (High) }\end{array}$ & III & II & I & I \\
\hline $\begin{array}{l}\text { >ERPG-1 / TEEL-1 } \\
\text { <ERPG-2 / TEEL-2 } \\
\text { (Moderate) }\end{array}$ & IV & III & II & I \\
\hline $\begin{array}{l}\text { <ERPG-1 / TEEL-1 } \\
\text { (Low) }\end{array}$ & IV & IV & III & III \\
\hline
\end{tabular}

Notes:

${ }^{1}$ Radiological consequences for the offsite receptor are evaluated in accordance with DOE-STD-3009-94, 2002, Preparation Guide for U.S. Department of Energy Nonreactor Nuclear Facility Documented Safety Analyses, Change Notice No. 2, Appendix A, U.S. Department of Energy, Washington D.C.

ERPG = emergency response planning guideline.

TEEL = Temporary Emergency Exposure Limit. 
Table 1-2. Onsite (100 m) Risk Bins.

\begin{tabular}{|c|c|c|c|c|}
\hline \multirow[b]{2}{*}{$\begin{array}{c}\text { Consequence category } \\
\text { (radiological/ } \\
\text { toxicological) }\end{array}$} & \multicolumn{4}{|c|}{ Event frequency } \\
\hline & $\begin{array}{c}<10^{-6} / y r \\
\text { Beyond extremely } \\
\text { unlikely }\end{array}$ & $\begin{array}{c}10^{-4} \text { to } 10^{-6} / \mathrm{yr} \\
\text { Extremely } \\
\text { unlikely }\end{array}$ & $\begin{array}{c}10^{-2} \text { to } 10^{-4} / \mathrm{yr} \\
\text { Unlikely }\end{array}$ & $\begin{array}{l}10^{-1} \text { to } 10^{-2} / \mathrm{yr} \\
\text { Anticipated }\end{array}$ \\
\hline $\begin{array}{l}>100 \text { rem } \\
>\text { ERPG-3 / TEEL-3 } \\
\text { (High) }\end{array}$ & III & II & I & I \\
\hline $\begin{array}{l}25 \text { to } 100 \text { rem } \\
\text { >ERPG- } 2 \text { / TEEL-2 } \\
<\text { ERPG-3 / TEEL-3 } \\
\text { (Moderate) }\end{array}$ & IV & III & II & I \\
\hline $\begin{array}{l}<25 \text { rem } \\
<\text { ERPG-2 / TEEL-2 } \\
\text { (Low) }\end{array}$ & IV & IV & III & III \\
\hline
\end{tabular}

Notes:

ERPG = emergency response planning guideline.

TEEL = Temporary Emergency Exposure Limit.

Environmental consequences are also assigned during the risk binning process. There are four categories of environmental consequences (E0, E1, E2, and E3, in order of increasing severity); these categories are defined in Table 1-3.

Table 1-3. Environmental Consequence Categories.

\begin{tabular}{|c|l|}
\hline Category & \multicolumn{1}{c|}{ Definition } \\
\hline E3 & Offsite discharge or discharge to groundwater \\
\hline E2 & Significant discharge onsite \\
\hline E1 & Localized discharge of hazardous material \\
\hline E0 & No significant environmental consequence \\
\hline
\end{tabular}

\subsection{RISK BINNING RESULTS}

A risk binning team meeting was conducted on July 17, 2002, to obtain consensus on the assignment of frequencies, consequences, and risk bins. The attendees represented a wide range of expertise in the areas of engineering, licensing, and operations, and included representatives from the U.S. Department of Energy, Office of River Protection. Appendix A lists the attendees and the organization each attendee represents. After the meeting, the risk binning results were distributed to the Technical Working Group (TWG) for review and concurrence. The final risk bin results, after comment resolution, are summarized in Tables 2-1 and 2-5. See RPP-15116, Proceedings of the Nuclear Working Group and the Technical Working Group. 


\subsection{MIXING OF INCOMPATIBLE MATERIALS REPRESENTATIVE ACCIDENT WITHOUT CONTROLS}

\subsubsection{Accident Scenario}

Large quantities of sodium hydroxide or sodium nitrite are added to DSTs, as necessary, to maintain the waste chemistry within the limits specified in the corrosion control program. These chemicals are delivered in tanker trucks and typically are added directly to the DST that requires chemical adjustment.

In the accident scenario without controls, the wrong chemical is delivered and 5,000 gal of concentrated sulfuric acid is added to a DST or 100-series SST. The receiving tank is assumed to contain sufficient carbonate waste to completely react with the incoming acid. The carbon dioxide formed is released into the tank headspace carrying with it a fraction of tank waste. It is assumed that the high-efficiency particulate air (HEPA) filters fail, contributing to the consequences. Condensation of the aerosol on the walls of the tank was assumed to be insignificant. The reaction was conservatively considered to be instantaneous. Aerosolized waste is released as a result of the tank pressurization.

\subsubsection{Frequency Determination}

A frequency of "unlikely" was qualitatively assigned to the mixing of incompatible materials representative accident. The scenario requires that the chemical vendor also produce bulk quantities of sulfuric acid, mistakenly fills the delivery truck with the wrong chemical, places incorrect placarding on the vehicle, and includes incorrect delivery paperwork. The highly corrosive substance would have to be shipped to the receiving facility without being noticed by delivery personnel or shipping and receiving personnel. The vehicle would have to be connected and the corrosive material delivered without notice by participating personnel. In addition the receiving tank would have to contain high concentrations of carbonate waste.

\subsubsection{Consequence Determination}

This scenario of a bulk addition of acid to a waste tank has not been previously analyzed. To provide an estimate of the radiological and toxicological consequences, calculations were performed and are documented in Appendix B. The accident scenario, without controls, assumes that a cargo tanker filled with 5,000 gal of $98 \%$ sulfuric acid $(18.7 \mathrm{M})$ is emptied into a waste tank instead of the chemical expected (e.g., caustic or sodium nitrite). The 5,000 gal assumption is conservative because the sulfuric acid would significantly exceed the weight that tanker trucks can transport. (While tanker trucks contain a nominal volume as large as 7,000 gal, they are limited by total weight of the filled tanker. Generally, the maximum weight that can be transported is $45,000 \mathrm{lb}$, which is the equivalent weight of 3,000 gal of sulfuric acid. The analysis conservatively assumes the tanker contains significantly more than the full weight capacity of sulfuric acid.) The rate of addition is conservatively assumed to be $175 \mathrm{gal} / \mathrm{min}$ based on RPP-14442, Calculation of Acid Flow Rate into DSTs (typical addition rates seen in the 
field range from 75 to $100 \mathrm{gal} / \mathrm{min}$ ). The receiving tank is assumed to contain sufficient carbonate waste to completely react with the incoming acid. The carbon dioxide formed is released into the tank headspace carrying with it a fraction of tank waste. It is assumed that the HEPA filters fail, contributing to the consequences. Condensation of the aerosol on the walls of the tank was assumed to be insignificant. The reaction was conservatively considered to be instantaneous. The contributors to the toxicological consequences are the HEPA filter release, the aerosolized waste, and sulfuric acid fumes.

The source term used for the aerosol is $10 \%$ solids and $90 \%$ liquids. While the reaction will occur in the liquid phase, agitation will occur in the vicinity of the incoming acid stream. The agitation will cause some fine solids to be suspended in liquid. Solids that are dense or have large particle sizes will not be suspended by the bubbles. As the bubbles rise/collide/consolidate and collapse much of the solids will be released. The inclusion of $10 \%$ solids in the aerosol is considered a conservative assumption. The radiological unit-liter doses (ULD) were taken from RPP-5924, Radiological Source Terms for Tank Farms Safety Analysis, and the toxicological sums of fractions (SOF) were taken from RPP-8369, Chemical Source Terms for Tank Farms Safety Analyses. The bounding ULDs and SOFs for DSTs and 100-series SSTs were selected for use in the analysis. The atmospheric dispersion factors are from RPP-13482, Atmospheric Dispersion Coefficients and Radiological/Toxicological Exposure Methodology for Use in Tank Farms.

Analysis assumptions and inputs are described below:

- 5,000 gal addition (conservative as this volume would exceed the weight that tanker trucks can transport)

- $175 \mathrm{gal} / \mathrm{min}$ rate of addition

- The acid is $98 \%$ sulfuric acid

- All the aerosol released is assumed to be respirable

- The ULD used for the aerosol in the analysis is $10 \%$ sludge and $90 \%$ liquids from the bounding DST or 100-series SST

- The SOF used for the aerosol in the analysis is $10 \%$ solids and $90 \%$ liquids from the bounding DST or 100 -series SST

- The receiving tank is assumed to contain sufficient carbonate waste to completely react with the incoming acid

- The pressurization resulting from the accident fails the HEPA filters

- The inventory on the HEPA filters is equivalent to that which would produce a contact dose rate of $200 \mathrm{mrem} / \mathrm{h}$

- Condensation of the aerosol on the walls of the tank was assumed to be insignificant 
- Instantaneous reaction (conservative; would require instantaneous mixing).

It is important to note that the key assumptions listed above were selected to maximize the calculated consequences of the inadvertent acid addition, and that it is the combination of conservative assumptions that drive the accident consequences. Each of the assumptions, the potential effect of changes in the assumption on the frequency or consequence bin (qualitatively judged), and the need to evaluate or protect the assumptions are detailed in Table 2-2.

\subsubsection{Assignment of Consequence Bins for the Onsite Radiological Receptor.}

Although the evaluation of consequences was intended to be qualitative, there were no previous analyses of an inadvertent large acid addition that could provide an additional frame of reference for the qualitative judgment. Therefore, the radiological consequences were estimated as shown in Appendix B. Also, while determining the offsite toxicological, onsite radiological, and onsite toxicological consequence bins, the meeting participants considered an actual operational experience where a transfer of unneutralized PUREX waste occurred. While the line between the valve pit and the distributor was damaged, there was no noticeable reaction with the tank waste (Occurrence \#85-34 [RPP-13121, Historical Summary of Occurrences from the Tank Farms Final Safety Analysis Report]). Table 2-3 compares the onsite radiological consequences of the bounding representative accident to the radiological risk evaluation guidelines. Since the bounding condition resulted in consequences that exceeded the moderate guideline to the onsite radiological receptor, the hazardous condition was assigned a consequence bin of "moderate" for the onsite radiological receptor.

\subsubsection{Assignment of Consequence Bins for the Onsite and Offsite Toxicological Receptor.}

As noted in the previous section, there were no previous analyses of an inadvertent large acid addition to influence the qualitative assignment of consequences. Thus, the toxicological consequences were also estimated as shown in Appendix B. Consequence bins were assigned based on the analysis presented in Appendix B and the occurrence discussed above. Table 2-4 compares the toxicological consequences of the bounding representative accident to the risk evaluation guidelines. Reviewing the consequences shows that the offsite toxicological consequences are low, while the moderate onsite toxicological consequences are exceeded for the bounding condition. Since the bounding condition resulted in low consequences to the offsite toxicological receptor, the represented hazardous condition was assigned a consequence bin of "low" for the offsite toxicological receptor. A consequence bin of "moderate" was assigned to the onsite toxicological receptor based on the results of the analysis. It should be noted that "moderate" consequences can only be seen from bulk additions. Smaller drum-sized additions will result in significantly lower consequences. The rate of addition will be much lower than $175 \mathrm{gal} / \mathrm{min}$. As drums are drained and the pump is transferred to other drums the addition rate is expected to average around $10 \mathrm{gal} / \mathrm{min}$. Since toxicological consequences are based on the rate of release, the consequences will be proportionately lower. Also, if off-gassing is initiated it is not credible to assume that the facility workers will continue to replace the empty drums with full drums in the midst of a cloud of gas. Therefore, once off-gassing begins only one to two drums would be added before the facility worker would self-evacuate, thus terminating the addition. 
RPP-12646 REV 4

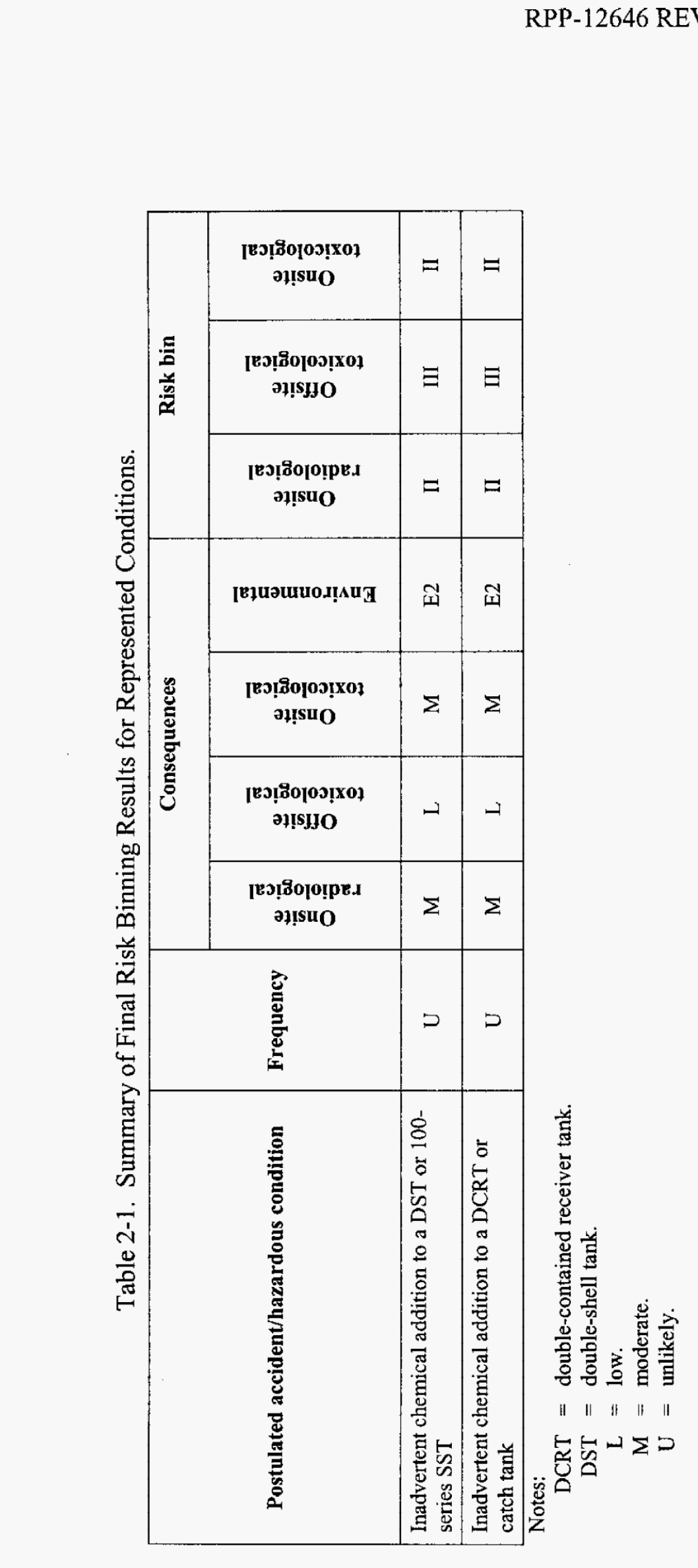


RPP-12646 REV 4

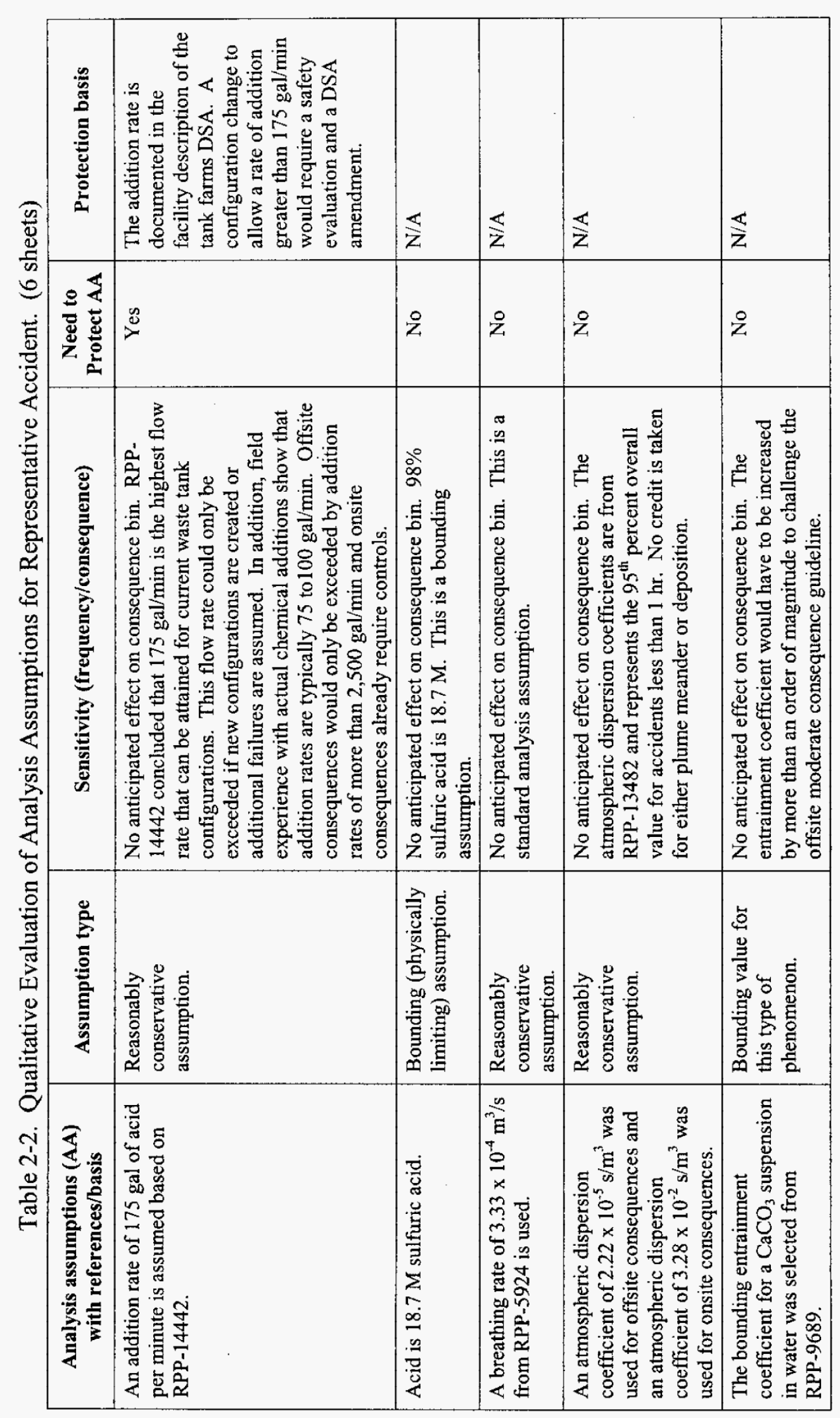


RPP-12646 REV 4

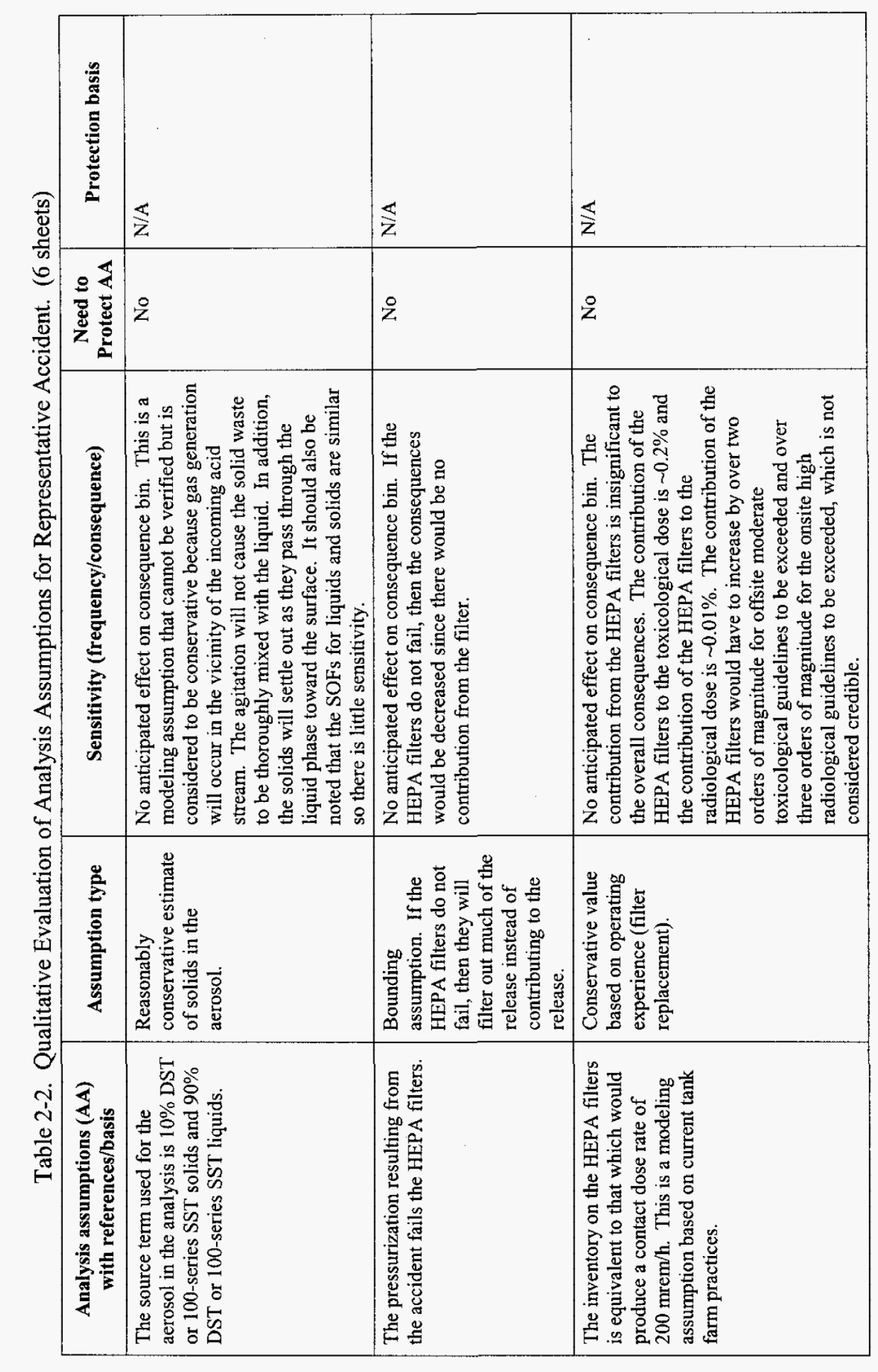


RPP-12646 REV 4

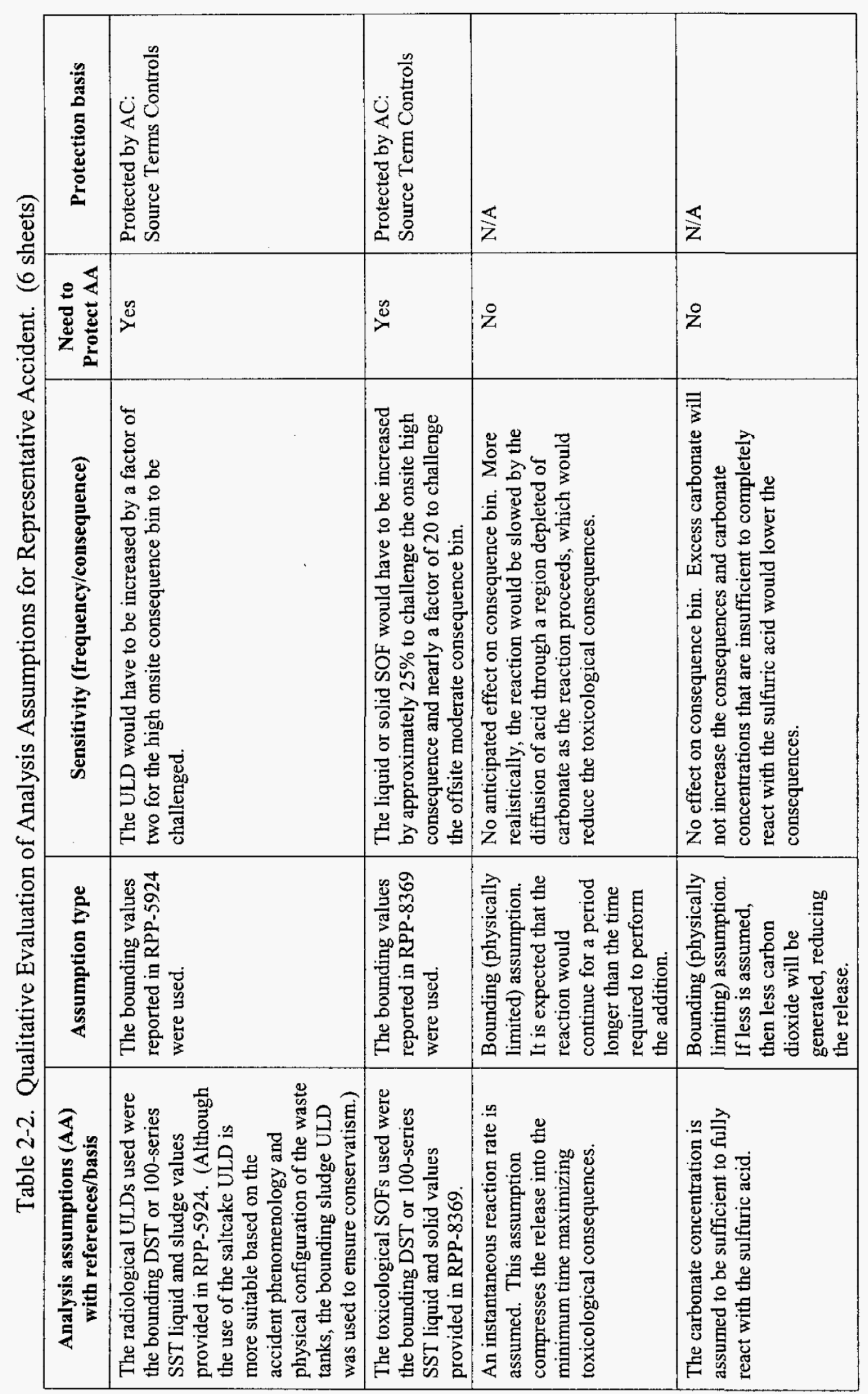

RPP 1264

\begin{tabular}{|c|c|c|c|c|c|}
\hline & 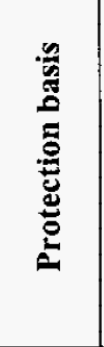 & 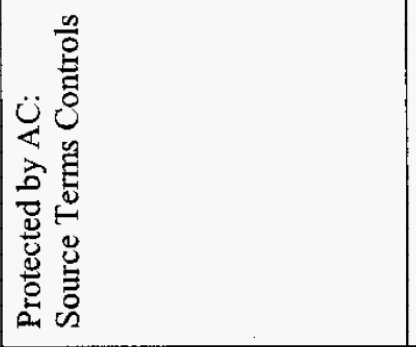 & 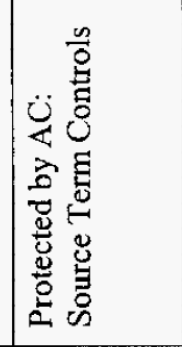 & 这 & $\mathbb{Z}$ \\
\hline 苞 & 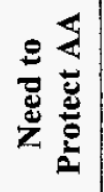 & ${ }_{\nu}^{\infty}$ & $\overbrace{\nu}^{\infty}$ & 足 & $z$ \\
\hline 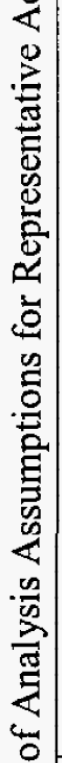 & 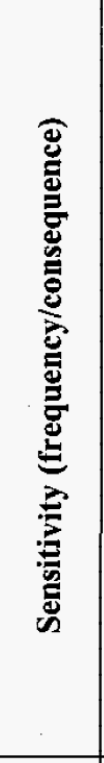 & 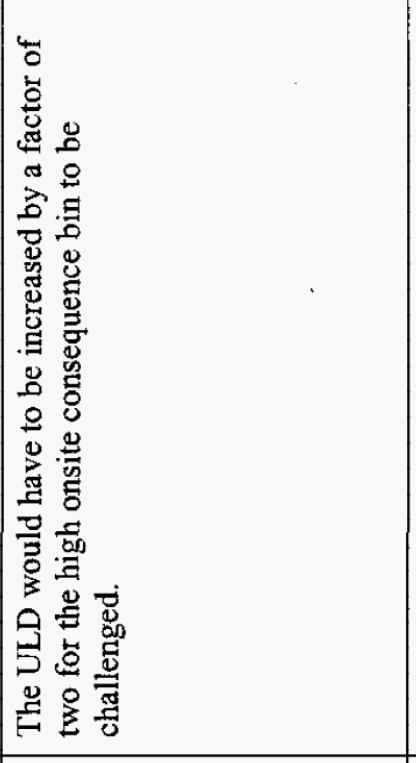 & 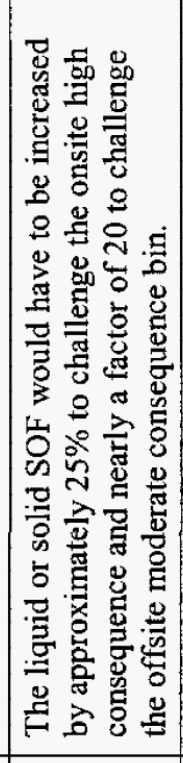 & 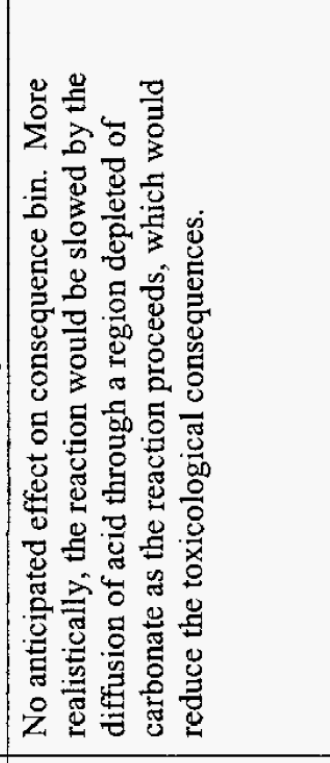 & 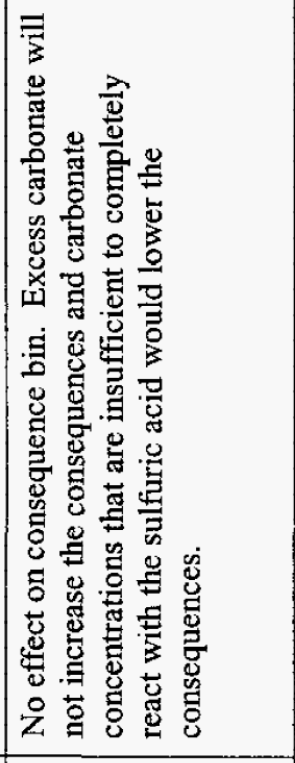 \\
\hline 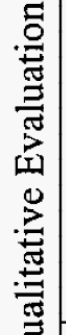 & 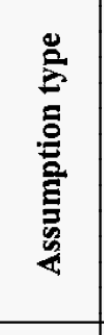 & 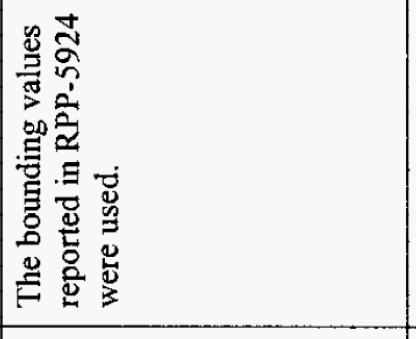 & 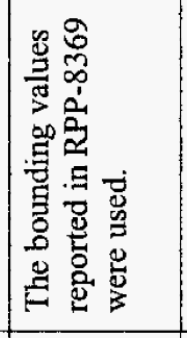 & 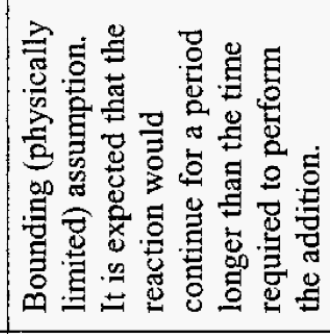 & 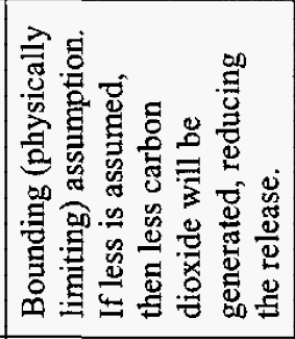 \\
\hline 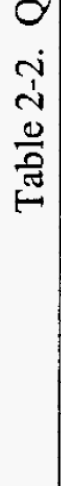 & 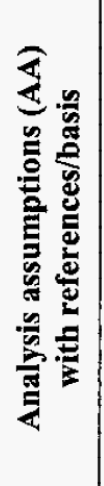 & 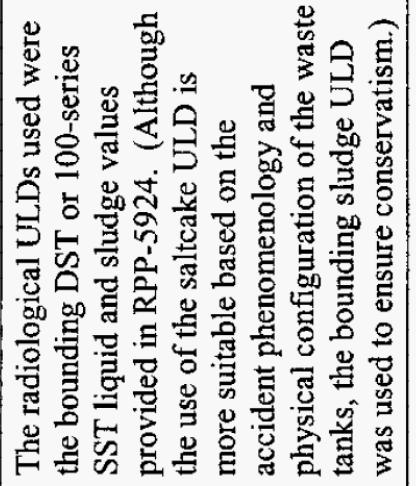 & 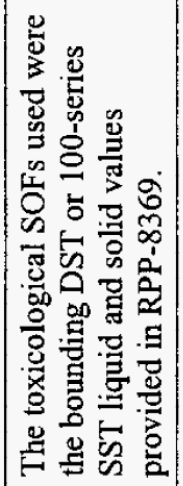 & 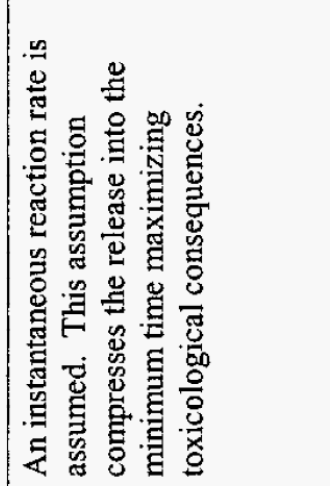 & 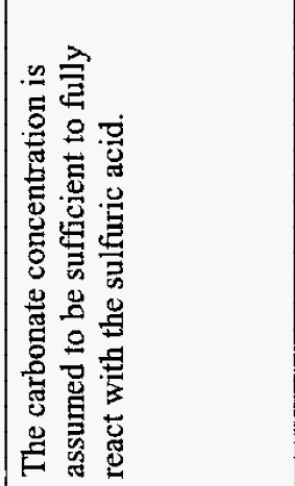 \\
\hline
\end{tabular}




\section{RPP-12646 REV 4}

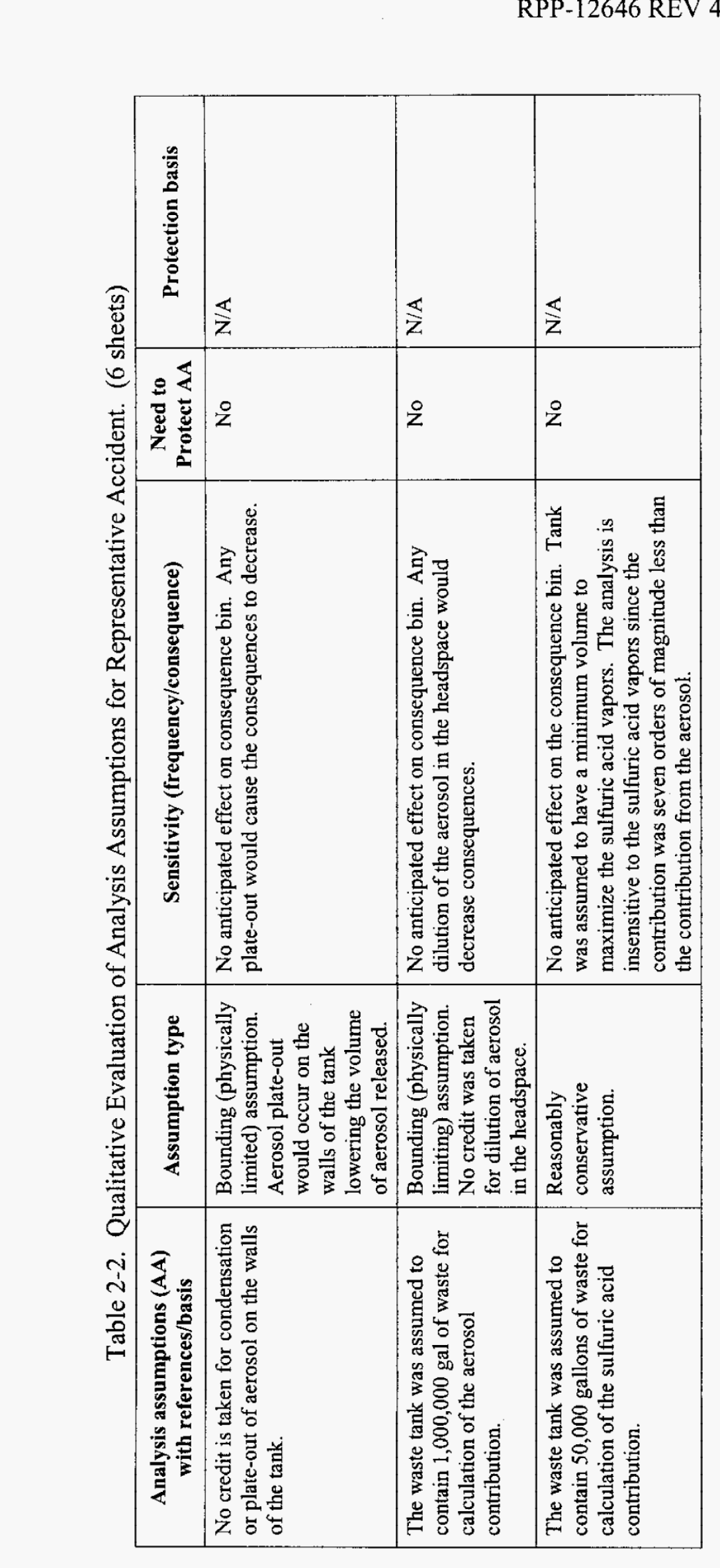

. 
RPP-12646 REV 4

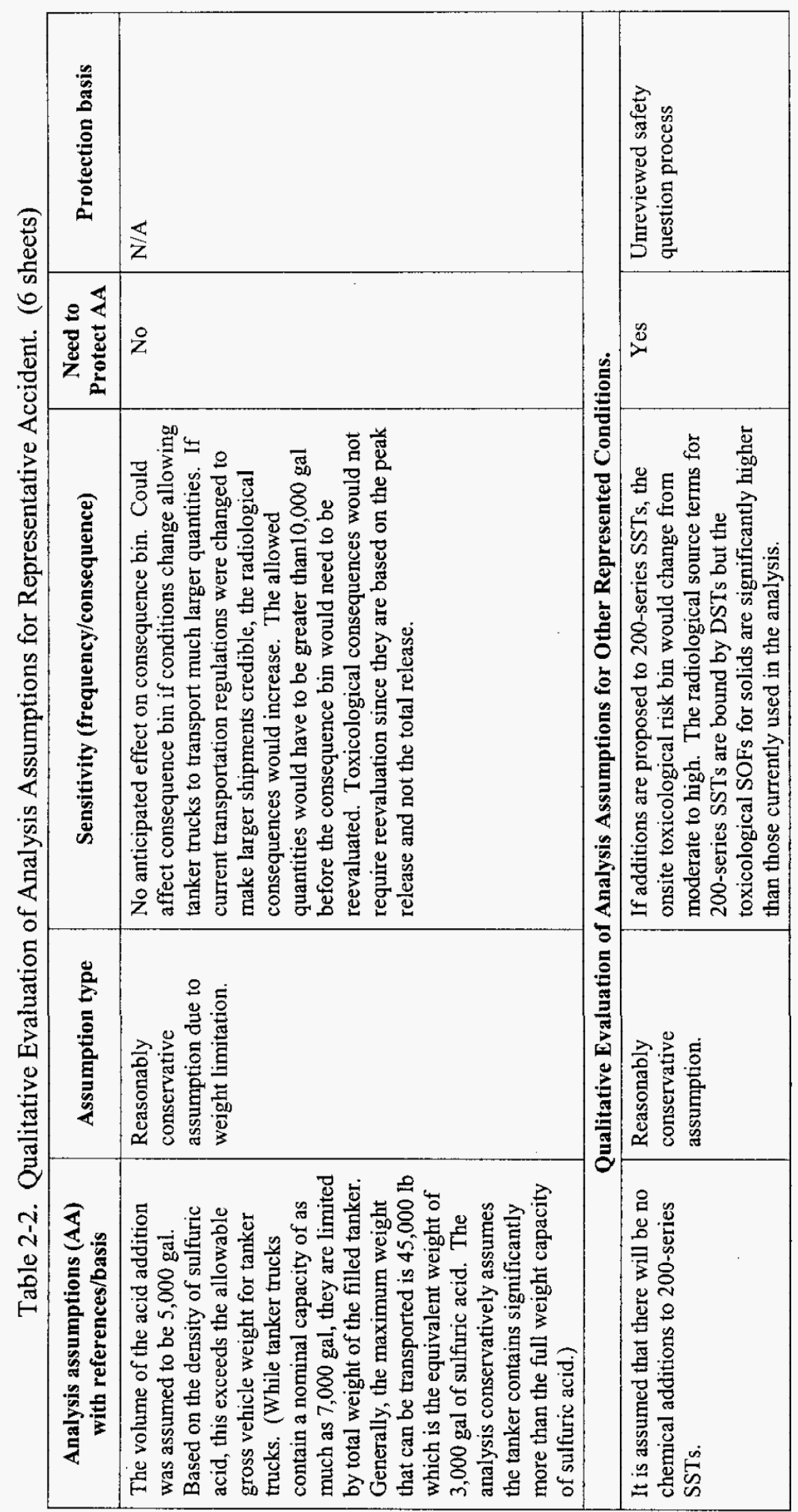




\section{RPP-12646 REV 4}

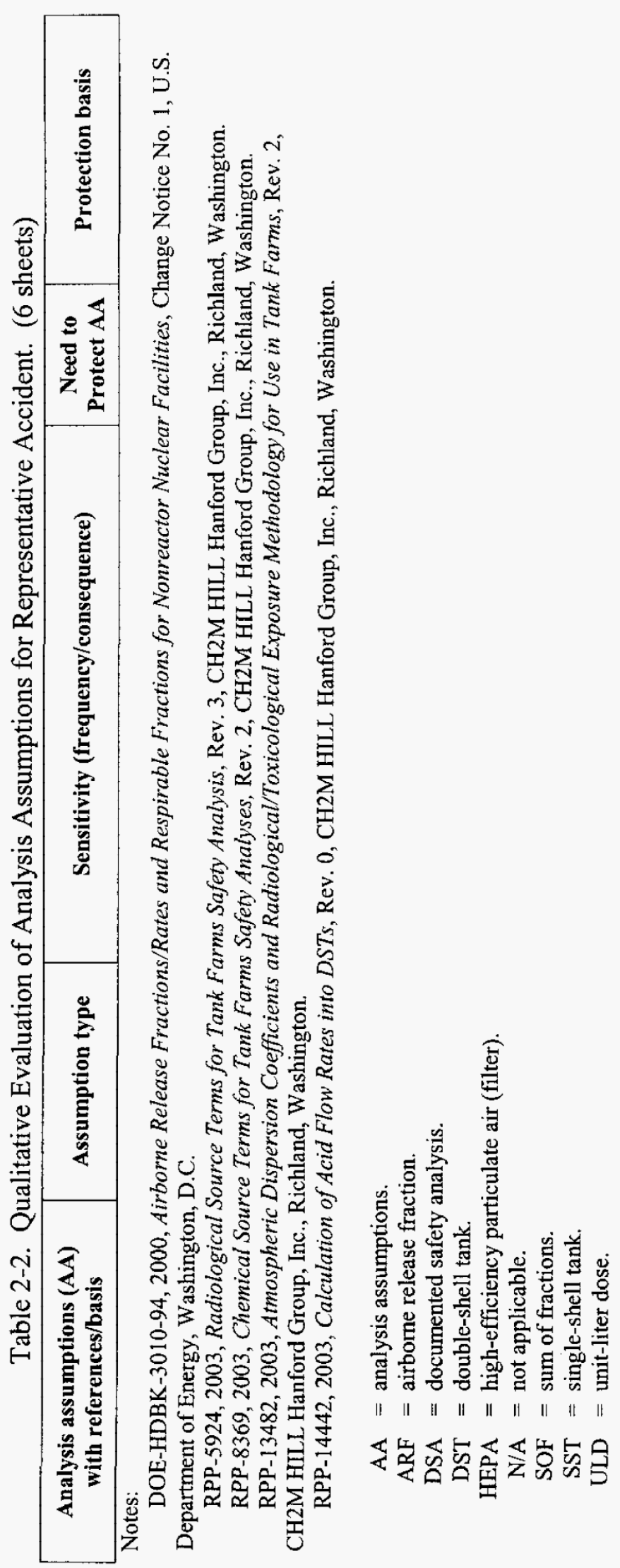




\section{RPP-12646 REV 4}

Table 2-3. Summary of Onsite Radiological Consequences for the Mixing of Incompatible Materials Without Controls.

\begin{tabular}{|l|c|c|c|}
\hline \multirow{2}{*}{ Accident } & \multicolumn{3}{|c|}{ Onsite Radiological Consequences } \\
\cline { 2 - 4 } & $\begin{array}{c}\text { Calculated dose } \\
\text { (rem) }\end{array}$ & $\begin{array}{c}\text { Moderate consequence } \\
\text { guideline } \\
\text { (rem) }\end{array}$ & $\begin{array}{c}\text { High consequence } \\
\text { guideline } \\
\text { (rem) }\end{array}$ \\
\hline $\begin{array}{l}\text { Mixing of } \\
\text { incompatible } \\
\text { materials }\end{array}$ & $4.3 \times 10^{1}$ & $2.5 \times 10^{1}$ & $1.0 \times 10^{2}$ \\
\hline
\end{tabular}

Table 2-4. Summary of Toxicological Consequences for the Mixing of Incompatible Materials Without Controls.

\begin{tabular}{|c|c|c|c|c|c|c|c|c|}
\hline \multirow{4}{*}{ Case } & \multicolumn{8}{|c|}{ Toxicological Consequences } \\
\hline & \multicolumn{4}{|c|}{ Onsite } & \multicolumn{4}{|c|}{ Offsite } \\
\hline & \multicolumn{2}{|c|}{$\begin{array}{c}\text { Moderate } \\
\text { consequence }\end{array}$} & \multicolumn{2}{|c|}{ High consequence } & \multicolumn{2}{|c|}{$\begin{array}{c}\text { Moderate } \\
\text { consequence }\end{array}$} & \multicolumn{2}{|c|}{ High consequence } \\
\hline & SOF & Guideline & SOF & Guideline & SOF & Guideline & SOF & Guideline \\
\hline $\begin{array}{l}\text { Mixing of } \\
\text { incompatible } \\
\text { materials }\end{array}$ & $2.3 \times 10^{+1}$ & $\begin{array}{c}1 \\
(\mathrm{ERPG}-1)\end{array}$ & $8.6 \times 10^{-1}$ & $\begin{array}{c}1 \\
(\mathrm{ERPG}-2)\end{array}$ & $9.2 \times 10^{-2}$ & $\begin{array}{c}1 \\
\text { (ERPG-2) }\end{array}$ & $1.5 \times 10^{-2}$ & $\begin{array}{c}1 \\
\text { (ERPG-3) }\end{array}$ \\
\hline
\end{tabular}

Notes:

ERPG $=$ emergency response planning guideline. SOF $=$ sum of fractions.

\subsubsection{Assignment of Environmental Consequences.}

Based on operational experience and the conservative calculations in Appendix B it was concluded that there is potential for material release to either the atmosphere or ground. Therefore, an environmental consequence of E2 was assigned to the mixing of incompatible materials representative accident.

\subsubsection{Assignment of Risk Bins.}

Table 2-1 summarizes the frequency and risk bin assignments for the mixing of incompatible materials accident scenario without controls. The assignment of risk bins is derived from the consequences and estimated frequency of the accident. The risk bin for the offsite toxicological receptor is III because the consequence is "low" and the frequency is "unlikely." The risk bin for the onsite toxicological receptor and the onsite radiological receptor is II since the consequence is "moderate" and the frequency is "unlikely." 


\subsection{MIXING OF INCOMPATIBLE MATERIALS ASSOCIATED HAZARDOUS CONDITIONS}

There are more than 40 hazardous conditions represented by the mixing of incompatible materials representative accident. (Note that the specific number of hazardous conditions reported in the hazard evaluation database may increase or decrease in the future based on changes in field configurations or operations.) The results of the risk binning process for these hazardous conditions are shown in the hazard evaluation database under the representative accidents 03 and 23. Included in the hazard evaluation database entries is a basis for each consequence and frequency.

Meeting participants considered process knowledge, operational history, and the conservatisms in the analysis when assigning consequence and frequency bins to the other represented hazardous conditions. The results are summarized in Table 2-5, and are discussed below.

- Small inadvertent addition. Inadvertent additions from small containers, such as 55-gal drums, was assigned a frequency of "unlikely" for reasons similar to the bounding case. The consequences were judged to be low since the total volume of potentially reactive acid is small and the credible rate of addition was much lower than the bounding case.

- Tank waste mixing with tank waste conditions that result in energetic reactions. Tank waste mixing with tank waste conditions were judged to be "extremely unlikely" because process history and knowledge have shown that mixing different tank wastes does not result in an energetic reaction (Reynolds 2001). Even if a reaction were assumed to occur, it was judged that it would be significantly less than the bounding case of 5,000 gal of concentrated sulfuric acid.

- Incompatible waste transfer from external sources (B Plant, T Plant, 222-S Laboratory, and PFP). Waste transfers from B Plant were judged to be "beyond extremely unlikely" since it is physically disconnected from tank farms. Transfers from PFP, T Plant, and 222-S Laboratory were judged to be "unlikely" due to the physical configuration and inventories of acids contained in the facilities. Even if a transfer was assumed to occur, it was judged to be significantly lower than the consequences of the bounding case of 5,000 gal of concentrated sulfuric acid.

- Toxic gas (ammonia) release during intrusive activity. Toxic gas releases due to intrusive activities were assigned a frequency of anticipated based on the history of tank farms. The consequences were shown to be low in WHC-SD-WM-CN-074. 


\section{RPP-12646 REV 4}
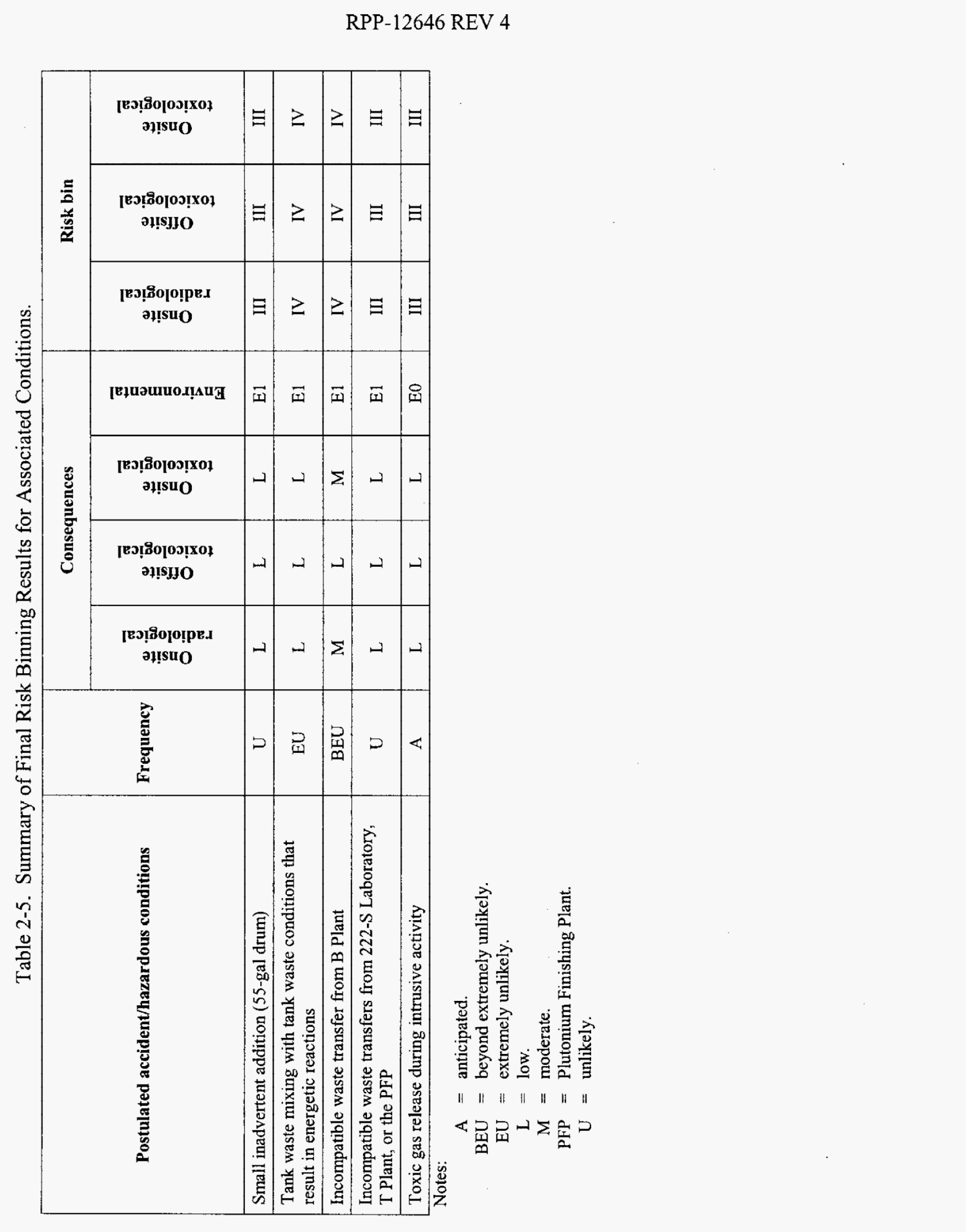
RPP-12646 REV 4

\subsection{CONTROL SELECTION}

After the allocation of risk bins, a group was empanelled to select controls for the represented hazardous conditions. A multidisciplinary group representing organizations both internal and external to the Tank Farm Contractor performed the selection of controls. The list of control decision makers is listed in Appendix C. Controls were considered and selected to prevent or mitigate consequences of the hazards that were identified as requiring controls.

\subsection{PROPOSED CONTROLS FOR THE MIXING OF INCOMPATIBLE MATERIALS REPRESENTATIVE ACCIDENT}

A summary of the representative accident, as well as a synopsis of the risk binning results, was presented to the control selection team. The group then proposed and discussed numerous potential mitigative and preventative controls for the representative accident. The possible mitigative controls proposed were:

- Headspace gas/vent gas monitoring

- Self-evacuation training

- Limit the chemical addition rate

- HEPA filter efficiency controls

- Activated carbon filtration of ventilation exhaust

- Scrubbing of ventilation gases with water/caustic solution

- Personal protective equipment

- Limited area access.

Possible preventative controls were also considered:

- Perform a pH analysis to ensure compatibility

- Verify procurement/delivery paperwork prior to additions

- Use an evaluated suppliers list including periodic reviews/audits of chemical vendor quality control and assurance programs

- Control volume of additions

- Eliminate the need for liquid chemical additions 


\subsection{SELECTED CONTROL FOR THE MIXING \\ OF INCOMPATIBLE MATERIALS \\ REPRESENTATIVE ACCIDENT}

\subsubsection{Control Selection}

The proposed controls were discussed and evaluated by the group. Control decision criteria are established in:

- Title 10, Code of Federal Regulations, Part 830, Subpart B, "Nuclear Safety Management" (10 CFR 830)

- DOE-STD-3009-94

- DOE G 421.1-2, Implementation Guide for Use in Developing Documented Safety Analyses to Meet Subpart B of 10 CFR 830

- DOE G 423.1-1, Implementation Guide for Use in Developing Safety Requirements

- Klein and Schepens (2003).

The control decision preference can be summarized as follows:

- Preventive controls over mitigative

- Passive controls over active control

- Engineering controls over administrative controls

- Controls with the highest reliability

- Controls closest to the hazard

- Controls with the lowest implementation and maintenance costs.

A consensus was reached based on the judgment of the participants to perform a $\mathrm{pH}$ analysis to ensure compatibility. This analysis is a reliable and effective preventive control. It is close to the hazard and can be implemented with minimal operational or budgetary impact. The other controls were eliminated because:

- Controlling the volume of the addition was considered unreliable and ineffective as a selected control.

- Monitoring the headspace gas/vent gas or limiting the chemical addition rate are mitigative controls that are considered unreliable.

- HEPA filter efficiency controls are mitigative controls that are only effective for nonbounding conditions as the HEPA filter fails in the analyzed accident.

- Activated carbon filtration of ventilation exhaust or the scrubbing of ventilation gases with water/caustic solution are mitigative controls that would require major plant modifications including additional safety analyses. 


\section{RPP-12646 REV 4}

- Verification of procurement/delivery paperwork prior to additions and the use of an evaluated suppliers list, including periodic reviews/audits of chemical vendor quality control and assurance programs, were not considered as effective as the selected control.

- Eliminating the need for liquid chemical additions would degrade the safe storage of waste by eliminating the current corrosion control program, and hinder the tank closure effort by eliminating many potential decontamination and decommissioning proposals.

- Self-evacuation training, limited area access, and personal protective equipment are effective controls for facility workers but were considered less effective for the onsite $(100 \mathrm{~m})$ worker.

\subsubsection{Format of the Selected Control}

Once the control was selected, options for how the control would be depicted were evaluated. The possibilities were:

- The control could be documented as a new standalone TSR administrative control (AC)

- The control could be a key element under a TSR AC (i.e., transfer controls)

- The control could be included in the SMPs:

- Reflected as a bullet point in the SMP AC, specifying the key elements

- Reflected as a bullet point in the SMP AC, with the details listed in the DSA

- Listed in the DSA description of the SMP.

After discussion, it was agreed to represent the preventative control as a standalone AC in the TSRs. A standalone AC most strongly links the basis and applicability of the control with the final disposition of the control.

The precise wording of the control was then considered. The key areas of discussion were on the use of "field testing," whether a specific pH should be defined, and whether SSTs, DCRTs, and catch tanks should be included in the applicability. The consensus resulted in Table 3-1. 
Table 3-1. Summary of Technical Safety Requirement Controls for Mixing of Incompatible Material.

\begin{tabular}{|l|l|l|}
\hline \multicolumn{1}{|c|}{ Control } & \multicolumn{1}{c|}{ Safety function } & Comments \\
\hline $\begin{array}{l}\text { Bulk Chemical Additions } \\
\begin{array}{l}\text { Perform field testing to verify that bulk } \\
\text { chemicals shipped in tanket trucks have a } \mathrm{pH} \geq 7 \\
\text { before addition to DSTs, 100-series SSTs, } \\
\text { DCRTs, and catch tanks. }\end{array}\end{array}$ & $\begin{array}{l}\text { Prevents inadvertent additions } \\
\text { of acids. }\end{array}$ & \\
\hline $\begin{array}{l}\text { Safety Management Programs } \\
\text { Measuring and test equipment program }\end{array}$ & $\begin{array}{l}\text { Ensures program is maintained } \\
\text { to control tank farm measuring } \\
\text { and test equipment used to } \\
\text { verify parameters to comply } \\
\text { with TSRs. }\end{array}$ & \\
\hline
\end{tabular}

Notes:

DST $=$ double-shell tank.

DCRT $=$ double-contained receiver tank.

TSR $=$ technical safety requirement.

It was noted during the evaluation that:

- The $\mathrm{AC}$ bases should address the following:

- The control does not apply to waste transfers; chemical delivery from drums (e.g., 55-gal drums) that connect to tank farm tanks or to waste transfer systems during chemical additions; or to additions of water or inhibited water. Inhibited water includes dilute concentrations of sodium hydroxide and sodium nitrite.

- DSTs, DCRTs, 100-series SSTs and catch tanks are the only tank farm facilities where the addition of bulk chemicals from tank trucks is authorized (i.e., within the scope of the DSA). The addition of bulk chemicals to 200-series SSTs to support proposed retrieval methods would require additional safety analysis.

- Clarification of the intent of "field testing." "Field testing" is intended to mean a test by the Tank Farm Contractor after receipt of the shipment but before addition of the chemical.

- The specific method(s) of testing for $\mathrm{pH}$ (e.g., litmus paper) will be identified and controlled by a TSR AC program for instrumentation and measuring and test equipment. Any special requirements for the identified testing method(s) will be developed and documented for program implementation. 


\section{RPP-12646 REV 4}

\subsection{CONTROL ALLOCATION}

Of the conditions grouped under the mixing of incompatible materials accident scenario, a few conditions were identified as requiring controls due to onsite toxicological consequences of the inadvertent addition of acid. For these cases, the standalone $\mathrm{AC}$ was allocated. This new $\mathrm{AC}$ requires that the $\mathrm{pH}$ of bulk chemical additions be verified before transferring, thereby preventing the accident. Also allocated for these cases was a measuring and test equipment program that stipulates that any required instrumentation is properly calibrated or functionally tested. Defense-in-depth features were also identified for some of the represented conditions and are described in RPP-14821, Technical Basis Document for Defense-In-Depth Features.

\subsection{REFERENCES}

10 CFR 830, "Nuclear Safety Management," Office of the Federal Register (FR 1810, Vol. 66, No. 7), January 10, 2001.

DOE G 421.1-2, 2001, Implementation Guide for Use in Developing Documented Safety Analyses to Meet Subpart B of 10 CFR 830, U.S. Department of Energy, Washington, D.C.

DOE G 423.1-1, 2001, Implementation Guide for Use in Developing Technical Safety Requirements, U.S. Department of Energy, Washington, D.C.

DOE-HDBK-3010-94, 2000, Airborne Release Fractions/Rates and Respirable Fractions for Nonreactor Nuclear Facilities, Change Notice No. 1, U.S. Department of Energy, Washington, D.C.

DOE-STD-3009-94, 2002, Preparation Guide for U.S. Department of Energy Nonreactor Nuclear Facility Documented Safety Analyses, Change Notice No. 2, U.S. Department of Energy, Washington, D.C.

Herting, D. L., 2003, Final Report for Tank 241-C-106 Sludge Dissolution, Phase II, (letter FH-0301877 to D. A. Reynolds, CH2M HILL Hanford Group, Inc., dated May 8) Fluor Hanford, Richland, Washington.

Klein, K. A., and R. J. Schepens, 2003, "Replacement of Previous Guidance Provided by RL and ORP” (letter 03-ABD-0047 to E. K. Thomson, Fluor Hanford Inc., and E. S. Aromi, CH2M HILL Hanford Group Inc., February 4), U.S. Department of Energy, and Office of River Protection, Richland, Washington.

Reynolds, D. A., 2001, "Potential for Tank Farm Systems to Give off Toxic Chemicals or Pressurize Due to Chemical Incompatibilities" (internal Memo 7G300-01-MAK-027, to K. R. Sandgren, October 9), CH2M HILL Hanford Group, Inc., Richland, Washington. 


\section{RPP-12646 REV 4}

RPP-5924, 2003, Radiological Source Terms for Tank Farms Safety Analysis, Rev. 3, CH2M HILL Hanford Group, Inc., Richland, Washington.

RPP-8369, 2003, Chemical Source Terms for Tank Farms Safety Analyses, Rev. 2, CH2M HILL Hanford Group, Inc., Richland Washington.

RPP-9689, 2006, Offsite Radiological Consequence Calculation for the Bounding Mixing of Incompatible Materials Accident, Rev. 4, CH2M HILL Hanford Group, Inc., Richland, Washington.

RPP-13121, 2003, Historical Summary of Occurrences from the Tank Farms Final Safety Analysis Report, Rev. 0, CH2M HILL Hanford Group, Inc., Richland, Washington.

RPP-13482, 2003, Atmospheric Dispersion Coefficients and Radiological/Toxicological Exposure Methodology for Use in Tank Farms, Rev. 2, CH2M HILL Hanford Group, Inc., Richland, Washington.

RPP-14286, 2003, Facility Worker Technical Basis Document, Rev. 1, CH2M HILL Hanford Group, Inc., Richland, Washington.

RPP-14442, 2003, Calculation of Acid Flow Rates into DSTs, Rev. 0, CH2M HILL Hanford Group, Inc., Richland, Washington.

RPP-14821, 2003, Technical Basis Document for Defense-In-Depth Features, Rev. 1, CH2M HILL Hanford Group, Inc., Richland, Washington.

RPP-15116, 2003, Proceedings of the Nuclear Working Group and the Technical Working Group, Rev. 0, CH2M HILL Hanford Group, Inc., Richland, Washington.

WHC-SD-WM-CN-074, 1997, Chemical Reaction in a DCRT Leading to a Toxic Release, Rev. 0-A, Westinghouse Hanford Company, Richland, Washington. 
RPP-12646 REV 4

APPENDIX A

RISK BINNING MEETING ATTENDEES 
RPP-12646 REV 4

This page intentionally left blank.

A-ii 


\section{APPENDIX A}

\section{RISK BINNING MEETING ATTENDEES}

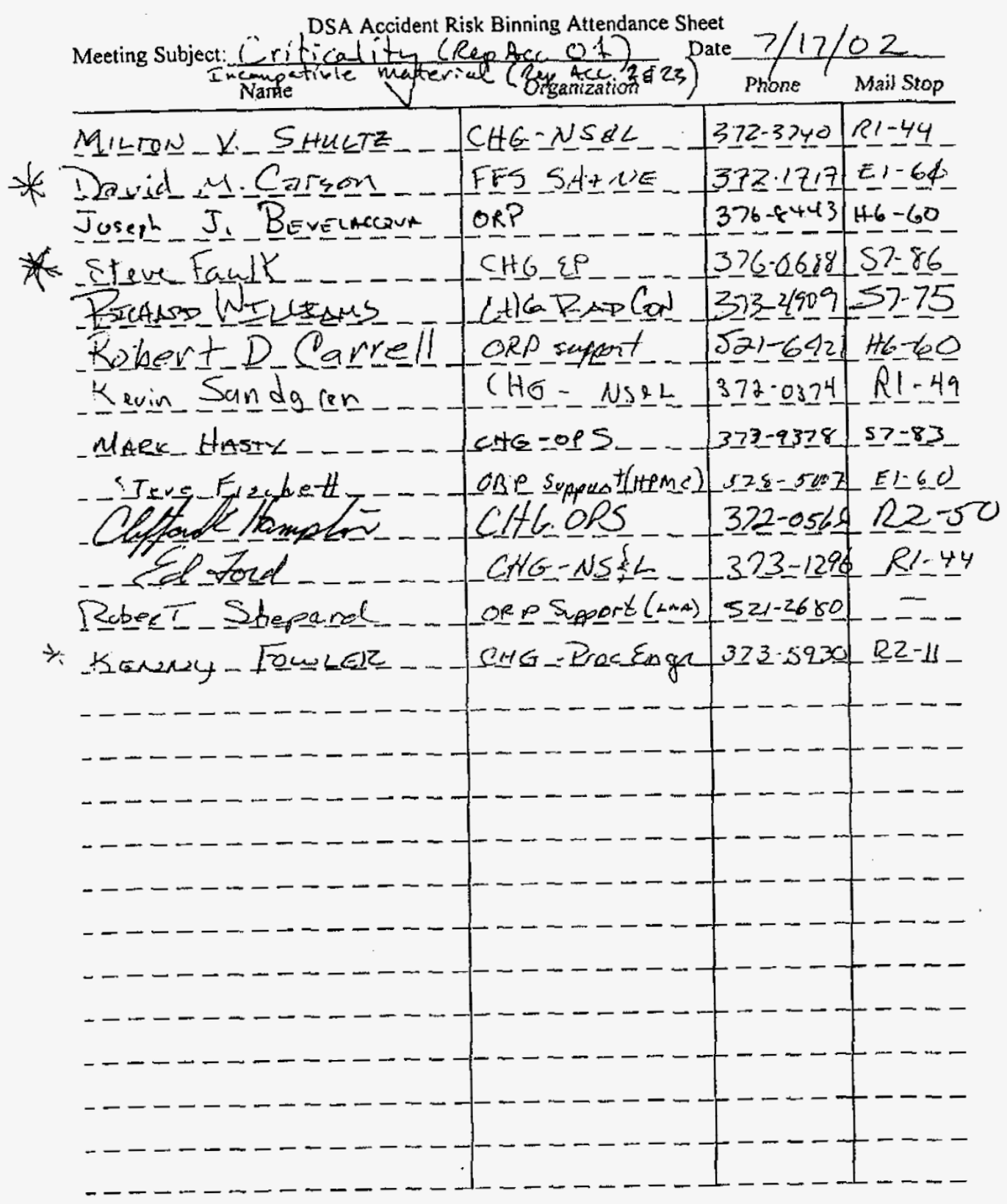

* only Criticalify 


\section{RPP-12646 REV 4}

\section{DSA Accident Risk Binning Attendance Sheet}

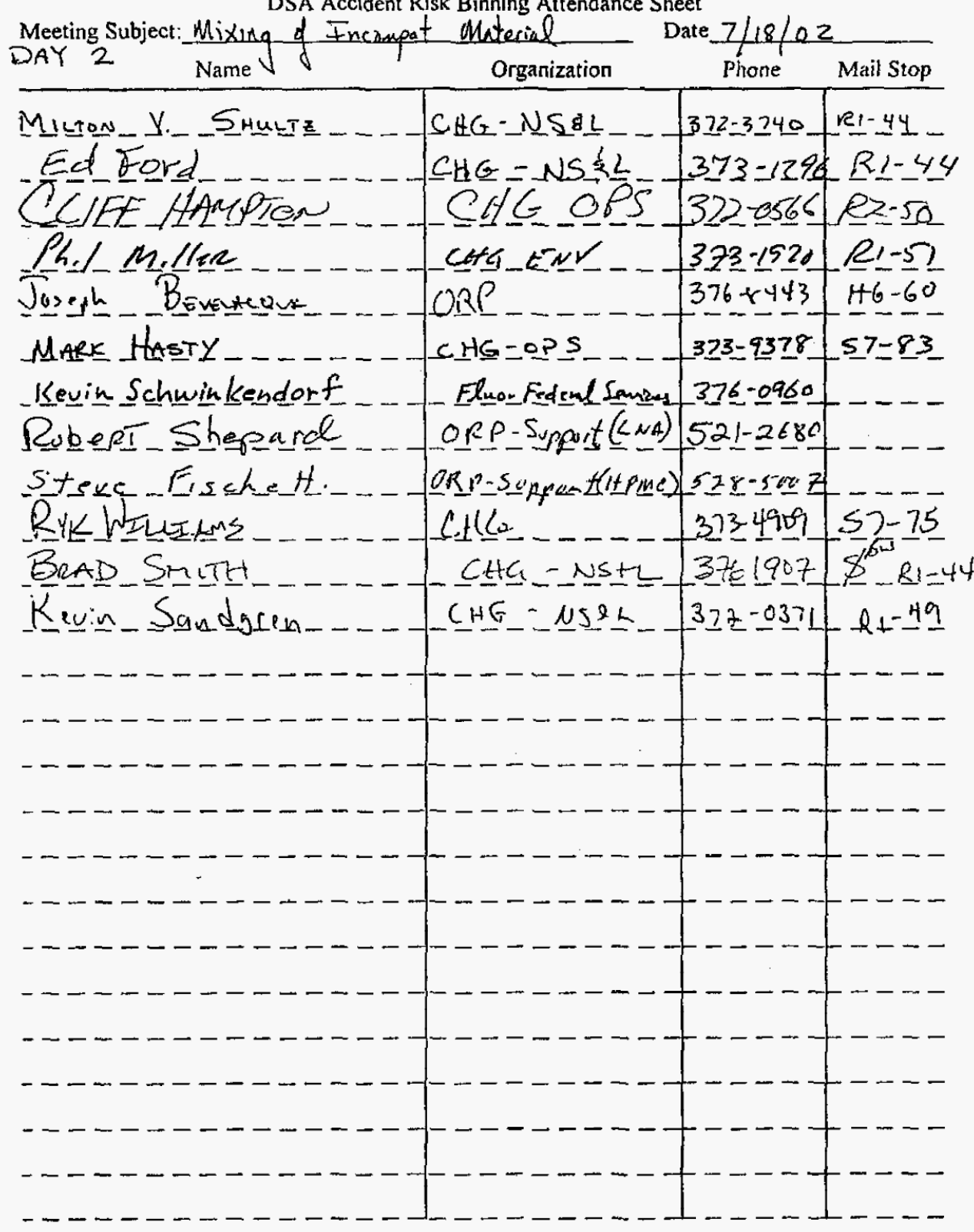

Miston_Y. SHULLTE . . . Ed Fore ch Hriplon Tor

MARK HASTY

- Sevin Schwinkendor

Stsuc Eischent....-

BRAD_SMIㅐ.

Kevin Sandgcen . . .

\section{CHG}

$3734909+57-75$

$37 \leq 1907 \$^{625}-2=44$ 
RPP-12646 REV 4

\section{APPENDIX B}

CONSEQUENCE CALCULATIONS FOR THE MIXING OF INCOMPATIBLE MATERIALS

B-i 
RPP-12646 REV 4

This page intentionally left blank.

B-ii 
RPP-12646 REV 4

\section{APPENDIX B \\ CONSEQUENCE CALCULATIONS FOR THE MIXING OF INCOMPATIBLE MATERIALS}

\section{B1.0 ONSITE RADIOLOGICAL CONSEQUENCES}

The Mixing of Incompatible Materials accident scenario, without controls, assumes that a cargo tanker filled with 5,000 gal of concentrated sulfuric acid $(18.7 \mathrm{M})$ is emptied into a double-shell tank (DST) or 100-series single-shell tank (SST) instead of the chemical expected (e.g., caustic or nitrite). The rate of addition is assumed to be $175 \mathrm{gal} / \mathrm{min}$ based on RPP-14442, Calculation of Acid Flow Rate into DSTs. The receiving tank is assumed to contain sufficient carbonate waste to completely react with the incoming acid. The carbon dioxide formed is released into the tank headspace carrying with it a fraction of tank waste. It is assumed that the highefficiency particulate air (HEPA) filters fail, contributing to the consequences. Condensation of the aerosol on the walls of the tank was assumed to be insignificant. The reaction was conservatively considered to be instantaneous. The contributors to the radiological consequences are the HEPA filter release and the aerosolized waste.

\section{B1.1 CONTRIBUTION OF AEROSOLIZED WASTE}

Sulfuric acid is a common industrial chemical. It is also typically transported at nearly $100 \%$ concentration $(18.7 \mathrm{M})$ to reduce costs and lower its corrosion potential. The reaction of sulfuric acid with sodium carbonate is shown below:

$$
\mathrm{H}_{2} \mathrm{SO}_{4}+\mathrm{Na}_{2} \mathrm{CO}_{3} \longrightarrow \mathrm{CO}_{2} \text { (gas) }+\mathrm{Na}_{2} \mathrm{SO}_{4}+\mathrm{H}_{2} \mathrm{O}
$$

It can be seen that each mole of sulfuric acid would result in the generation of one mole of carbon dioxide.

Calculating the total release of carbon dioxide:

$(5,000 \mathrm{gal})(3.785 \mathrm{~L} / \mathrm{gal})(18.7 \mathrm{~g}$ moles $/ \mathrm{L})(44 \mathrm{~g} / \mathrm{g}$ mole $)=1.56 \times 10^{7}$ grams carbon dioxide $=1.56 \times 10^{4} \mathrm{~kg}$ carbon dioxide

or:

$(5,000 \mathrm{gal})(3.785 \mathrm{~L} / \mathrm{gal})(18.7 \mathrm{~g}$ moles $/ \mathrm{L})(24.5 \mathrm{~L} / \mathrm{g}$ mole $)=8.67 \times 10^{6} \mathrm{~L}$ carbon dioxide

where:

$5,000 \mathrm{gal}=$ assumed volume of sulfuric acid addition

$3.785 \mathrm{~L} / \mathrm{gal}=$ conversion factor (CRC Handbook of Chemistry and Physics [Weast 1981])

$18.7 \mathrm{~g}$ moles $/ \mathrm{L}=$ molarity of concentrated $98 \%$ sulfuric acid (Weast 1981 )

$44 \mathrm{~g} / \mathrm{g}$ mole $\quad=$ molecular weight of carbon dioxide (Weast 1981) 


$$
\begin{aligned}
24.5 \mathrm{~L} / \mathrm{g} \text { mole } & =\text { the volume of carbon dioxide gas at } 25{ }^{\circ} \mathrm{C}(298 \mathrm{~K}) \\
& =(22.4 \mathrm{~L} / \mathrm{g} \text { mole at } 273 \mathrm{~K})(298 \mathrm{~K} / 273 \mathrm{~K}) .
\end{aligned}
$$

The volume of aerosol carried off by the waste can be estimated using an entrainment coefficient E:

$$
\mathrm{E}=\text { Volume aerosol/Volume gas through the surface }
$$

At low superficial gas velocities discrete bubbles rise through the pool uniformly and steadily. This flow pattern is classified as the bubbly flow regime. When superficial gas velocity exceeds the threshold value $\left(j_{g, t}\right)$ the flow regime transitions from bubbly flow to churn turbulent flow which is characterized by nonuniform bubbles rising in a more random manner. The transitional superficial velocity can be found in RPP-9689, Offsite Radiological Consequence Calculation for the Bounding Mixing of Incompatible Materials Accident:

$$
\mathrm{j}_{\mathrm{g}, \mathrm{t}}=0.3\left[(\sigma \mathrm{g}) /\left(\rho_{\mathrm{f}}\right)\right]^{1 / 4}=4.8 \times 10^{-2} \mathrm{~m} / \mathrm{s}
$$

where:

$\sigma$ is the liquid surface tension, $0.072 \mathrm{~kg} / \mathrm{s}^{2}$ for water against air at $25{ }^{\circ} \mathrm{C}$ (Weast 1981) $\mathrm{g}$ is the gravitational constant, $9.81 \mathrm{~m} / \mathrm{s}^{2}$

$\rho_{\mathrm{f}}$ is the assumed liquid density, $1.1 \times 10^{3} \mathrm{~kg} / \mathrm{m}^{3}$.

The superficial velocity $\left(\mathrm{j}_{\mathrm{g}}\right)$ for carbon dioxide generation can be calculated:

$$
\mathrm{j}_{\mathrm{g}}=\left[(9.1 \mathrm{~kg} / \mathrm{s}) /\left(1.8 \mathrm{~kg} / \mathrm{m}^{3}\right)\right]\left[(9.2 \mathrm{~m}) /\left(3.79 \times 10^{3} \mathrm{~m}^{3}\right)\right]=1.2 \times 10^{-2} \mathrm{~m} / \mathrm{s}
$$

where:

$$
\begin{aligned}
9.1 \mathrm{~kg} / \mathrm{s} & =\text { the carbon dioxide generation rate } \\
& =\left(1.56 \times 10^{4} \mathrm{~kg} \mathrm{CO}\right) /[\{(5,000 \text { gal }) /(175 \mathrm{gal} / \mathrm{min})\}(60 \mathrm{~s} / \mathrm{min})] \\
9.2 \mathrm{~m} & =\text { depth of waste in tank [a full tank is assumed }] \\
3.79 \times 10^{3} \mathrm{~m}^{3} & =\text { waste volume }[1,000,000 \text { gal assumed volume }] \\
1.8 \mathrm{~kg} / \mathrm{m}^{3} & =\text { density of gas at } 25^{\circ} \mathrm{C}\left[(44.01 \mathrm{~kg} / \mathrm{kg} \text { mole }) /\left(24.5 \mathrm{~m}^{3} / \mathrm{kg} \mathrm{mole}\right) .\right.
\end{aligned}
$$

Since the superficial velocity is less than the threshold velocity, the applicable flow regime is bubbly flow.

The radiological source term used for the aerosol in this analysis is $10 \%$ DST sludge and $90 \%$ DST supernatant. (The bounding DST radiological source term also bounds the radiological source term of the 100-series SSTs.) Gas generation will occur in the vicinity of the incoming acid stream. The agitation caused by the gas generation will not cause the solid waste to be thoroughly mixed with the liquid. In addition, the solids will settle out as they pass through the liquid phase toward the surface. The inclusion of $10 \%$ solids in the aerosol is a conservative assumption. The radiological unit-liter dose (ULD) for the waste is from RPP-5924, Radiological Source Terms for Tank Farms Safety Analysis. 
The waste aerosolized is calculated as follows:

$$
\left(8.67 \times 10^{6} \mathrm{~L}\right)\left(2.3 \times 10^{-7}\right)=2.0 \mathrm{~L}
$$

where:

$2.3 \times 10^{-7}=$ bounding entrainment coefficient for $\mathrm{CaCO}_{3}$ suspension in water (RPP-9689) Given

$$
\begin{aligned}
& \text { ULD for DST liquids }= \\
& \begin{aligned}
\text { ULD for DST sludge }= & 1.0 \times 10^{3} \mathrm{~Sv} / \mathrm{L}(\mathrm{RPP}-5924) \\
\text { ULD for aerosol } & =\left[\left(1.0 \times 10^{5} \mathrm{~Sv} / \mathrm{L}(\mathrm{RPP}-5924)\right.\right. \\
& \left.\left.=1.99 \times 10^{4} \mathrm{~Sv} / \mathrm{L}\right)(0.9)\right]+\left[\left(1.9 \times 10^{5} \mathrm{~Sv} / \mathrm{L}\right)(0.1)\right]
\end{aligned}
\end{aligned}
$$

Onsite aerosol dose $=($ aerosol released) $($ onsite $\chi / Q)$ (onsite ULD) (breathing rate)

$$
\begin{aligned}
\text { Onsite } \mathrm{D}_{\text {aerosol }} & =(2.0 \mathrm{~L})\left(0.0328 \mathrm{~s} / \mathrm{m}^{3}\right)\left(1.99 \times 10^{4} \mathrm{~Sv} / \mathrm{L}\right)\left(3.33 \times 10^{-4} \mathrm{~m}^{3} / \mathrm{s}\right) \\
& =4.3 \times 10^{-1} \mathrm{~Sv}
\end{aligned}
$$

where:

$$
\begin{aligned}
0.0328 \mathrm{~s} / \mathrm{m}^{3}= & \text { onsite } \chi / \mathrm{Q}(\mathrm{RPP}-13482, \text { Atmospheric Dispersion Coefficients and } \\
& \begin{array}{l}
\text { Radiological/Toxicological Exposure Methodology for Use in Tank } \\
\text { Farms) }
\end{array} \\
3.33 \times 10^{-4} \mathrm{~m}^{3} / \mathrm{s}= & \text { breathing rate (RPP-5924). }
\end{aligned}
$$

\section{B1.2 CONTRIBUTION OF THE HIGH-EFFICIENCY PARTICULATE AIR FILTER}

Since a significant quantity of carbon dioxide is released, it is assumed that the tank pressurizes sufficiently to fail the HEPA filters.

Bounding HEPA filter dose due to overpressure $\quad=4.0 \times 10^{-5} \mathrm{~Sv}$ (RPP-13437, Technical Basis Document for Ventilation System Filtration Failures Leading to Unfiltered Release).

\section{B1.3 TANK PRESSURIZATION}

It can be seen that the production of carbon dioxide reaches a significant volume. It was postulated that the rate of gas production would be sufficient to challenge the 55 to $60 \mathrm{lb} / \mathrm{in}^{2}$ gauge failure pressure for DSTs or the 11 to $12 \mathrm{lb} / \mathrm{in}^{2}$ gauge failure pressure for SSTs (WHC-SD-TWR-RPT-003, DELPHI Expert Panel Evaluation of Hanford High Level Waste Tank Failure Modes and Release Quantities). 
The rate of production can be found by:

$$
\begin{aligned}
& (175 \mathrm{gal} / \mathrm{min})(3.785 \mathrm{~L} / \mathrm{gal})(1 \mathrm{~min} / 60 \mathrm{~s})(18.7 \mathrm{~g} \mathrm{moles} / \mathrm{L})(24.5 \mathrm{~L} / \mathrm{g} \text { mole })=5.06 \times 10^{3} \mathrm{~L} / \mathrm{s} \\
& =5.06 \mathrm{~m}^{3} / \mathrm{s}
\end{aligned}
$$

where:

$$
\begin{array}{ll}
175 \mathrm{gal} / \mathrm{min} & =\text { rate of sulfuric acid addition (RPP-14442) } \\
3.785 \mathrm{~L} / \mathrm{gal} & =\text { conversion factor (Weast } 1981) \\
18.7 \mathrm{~g} \mathrm{moles} / \mathrm{L}= & \text { molarity of concentrated } 98 \% \text { sulfuric acid (Weast 1981) } \\
44 \mathrm{~g} / \mathrm{g} \mathrm{mole} & =\text { molecular weight of carbon dioxide (Weast 1981) } \\
24.5 \mathrm{~L} / \mathrm{g} \text { mole }= & \text { the volume of carbon dioxide gas at } 1 \mathrm{~atm}\left(14.7 \mathrm{lb} / \mathrm{in}^{2}\right. \text { absolute) and } \\
& 25^{\circ} \mathrm{C}(298 \mathrm{~K}) \\
= & (22.4 \mathrm{~L} / \mathrm{g} \text { mole at } 273 \mathrm{~K})(298 \mathrm{~K} / 273 \mathrm{~K}) .
\end{array}
$$

Tank pressurization as a function of gas flowrate was calculated in HNF-4240, Organic Solvent Topical Report. When all the vents were considered it was found that it would take a flowrate of nearly $14 \mathrm{~m}^{3} / \mathrm{s}$ to pressurize a tank to $14 \mathrm{lb} / \mathrm{in}^{2}$ gauge $\left(28.7 \mathrm{lb} / \mathrm{in}^{2}\right.$ absolute). The number and geometry of vent paths vary from tank to tank; however, the tank presented in HNF-4240, used for the vent path calculation (241-C-103), is representative of all SSTs. For all SSTs, tank farm Engineering has judged the gas production rate is still bounded by the ventilation capacity at $11 \mathrm{lb} / \mathrm{in}^{2}$ gauge (conservatively estimated SST tank pressure [WHC-SD-TWR-RPT-003]). In order to compare volumetric flowrates of gaseous materials, they need to be adjusted to the same reference pressure. Converting the $14 \mathrm{~m}^{3} / \mathrm{s}$ flowrate at $28.7 \mathrm{lb} / \mathrm{in}^{2}$ absolute pressure to a pressure of $14.7 \mathrm{lb} / \mathrm{in}^{2}$ absolute ( $\left.1 \mathrm{~atm}\right)$ results in a flowrate of $27 \mathrm{~m}^{3} / \mathrm{s}$. Thus, it can be seen that the production rate of carbon dioxide is less than a fifth of what is required to pressurize the tank to $14 \mathrm{lb} / \mathrm{in}^{2}$ gauge. The flowrate of carbon dioxide is estimated to pressurize the tank to $2.6 \mathrm{lb} / \mathrm{in}^{2}$ gauge. Therefore, any additional release due to tank failure is not considered credible.

\section{B1.4 OVERALL ONSITE RADIOLOGICAL CONSEQUENCES}

Total onsite radiological consequences $=($ aerosol contribution $)+($ HEPA contribution $)$

$$
\begin{aligned}
\text { Onsite } \mathrm{D}_{\text {Total }} & =\left(4.3 \times 10^{-1} \mathrm{~Sv}\right)+\left(4.0 \times 10^{-5} \mathrm{~Sv}\right)=4.3 \times 10^{-1} \mathrm{~Sv} \\
& =4.3 \times 10^{+1} \mathrm{rem} .
\end{aligned}
$$

\section{B2.0 TOXICOLOGICAL CONSEQUENCES}

The Mixing of Incompatible Materials accident scenario, without controls, assumes that a cargo tanker filled with 5,000 gal of concentrated sulfuric acid (18.7 M) is emptied into a DST or 100 -series SST, instead of the chemical expected (e.g., caustic or nitrite). The rate of addition is assumed to be $175 \mathrm{gal} / \mathrm{min}$, which is considered to be a reasonably conservative flow rate (RPP-14442). The receiving tank is assumed to contain sufficient carbonate waste to completely react with the incoming acid. The carbon dioxide formed is released into the tank headspace carrying with it a fraction of tank waste. It is assumed that the HEPA filters fail, contributing to 
RPP-12646 REV 4

the consequences. Condensation of the aerosol on the walls of the tank was assumed to be insignificant. The reaction was conservatively considered to be instantaneous. The contributors to the toxicological consequences are the HEPA filter release, the aerosolized waste, and sulfuric acid fumes.

\section{B2.1 CONTRIBUTION FROM AEROSOLIZED WASTE}

Sulfuric acid is a common industrial chemical. It is also typically transported at nearly $100 \%$ concentration $(18.7 \mathrm{M})$ to reduce costs and lower its corrosion potential. The reaction of sulfuric acid with sodium carbonate is shown below:

$$
\mathrm{H}_{2} \mathrm{SO}_{4}+\mathrm{Na}_{2} \mathrm{CO}_{3} \longrightarrow \mathrm{CO}_{2}(\text { gas })+\mathrm{Na}_{2} \mathrm{SO}_{4}+\mathrm{H}_{2} \mathrm{O}
$$

It can be seen that each mole of sulfuric acid would result in the generation of one mole of carbon dioxide.

Calculating the rate of release of carbon dioxide:

$(175 \mathrm{gal} / \mathrm{min})(3.785 \mathrm{~L} / \mathrm{gal})(1 \mathrm{~min} / 60 \mathrm{~s})(18.7 \mathrm{~g} \mathrm{moles} / \mathrm{L})(44 \mathrm{~g} / \mathrm{g} \mathrm{mole})=9.08 \times 10^{3} \mathrm{~g} / \mathrm{s}$

$(175 \mathrm{gal} / \mathrm{min})(3.785 \mathrm{~L} / \mathrm{gal})(1 \mathrm{~min} / 60 \mathrm{~s})(18.7 \mathrm{~g}$ moles $/ \mathrm{L})(24.5 \mathrm{~L} / \mathrm{g} \mathrm{mole})=5.06 \times 10^{3} \mathrm{~L} / \mathrm{s}$

where:

$175 \mathrm{gal} / \mathrm{min}=$ rate of sulfuric acid addition (RPP-14442)

$3.785 \mathrm{~L} / \mathrm{gal}=$ conversion factor (Weast 1981)

$18.7 \mathrm{~g}$ moles $/ \mathrm{L}=$ molarity of concentrated $98 \%$ sulfuric acid (Weast 1981)

$44 \mathrm{~g} / \mathrm{g}$ mole $=$ molecular weight of carbon dioxide (Weast 1981)

$24.5 \mathrm{~L} / \mathrm{g}$ mole $=$ the volume of carbon dioxide gas at $25^{\circ} \mathrm{C}(298 \mathrm{~K})$

$=(22.4 \mathrm{~L} / \mathrm{g}$ mole at $273 \mathrm{~K})(298 \mathrm{~K} / 273 \mathrm{~K})$.

The toxicological source term used for the aerosol in this analysis is $10 \%$ solids and $90 \%$ liquids from the bounding DST or 100-series SST. Gas generation will occur in the vicinity of the incoming acid stream. The agitation caused by the gas generation will not cause the solid waste to be thoroughly mixed with the liquid. In addition, the solids will settle out as they pass through the liquid phase toward the surface. The inclusion of $10 \%$ solids in the aerosol is a conservative assumption. The toxicological sums of fractions (SOF) for the waste are from RPP-8369, Chemical Source Terms for Tank Farms Safety Analyses.

Since the superficial velocity is less than the threshold velocity, the applicable flow regime is bubbly flow (as shown above).

The waste aerosolized is calculated as follows:

$$
\begin{aligned}
\left(5.06 \times 10^{3} \mathrm{~L} / \mathrm{s}\right)\left(2.3 \times 10^{-7}\right) & =1.16 \times 10^{-3} \mathrm{~L} / \mathrm{s} \\
& =1.16 \times 10^{-6} \mathrm{~m}^{3} / \mathrm{s} .
\end{aligned}
$$




\section{RPP-12646 REV 4}

where:

$2.3 \times 10^{-7}=$ bounding entrainment coefficient for $\mathrm{CaCO}_{3}$ suspension in water (RPP-9689)

\section{B2.1.1 Onsite Contribution of Aerosolized Waste}

Given

Onsite, high consequence SOF multiplier for bounding DST or 100-series SST liquids $=1.27 \times 10^{7}$ (RPP-8369)

Onsite, high consequence SOF multiplier for bounding DST or 100-series SST solids $=9.80 \times 10^{7}(\mathrm{RPP}-8369)$

Onsite aerosol, high consequence SOF multiplier $=\left[\left(1.27 \times 10^{7}\right)(0.9)\right]+\left[\left(9.80 \times 10^{7}\right)(0.1)\right]$

$$
=2.12 \times 10^{7} \text {. }
$$

And

Onsite, moderate consequence SOF multiplier for bounding DST or 100-series SST liquids $=5.73 \times 10^{8}(\mathrm{RPP}-8369)$

Onsite, moderate consequence SOF multiplier for bounding DST or 100-series SST solids $=7.77 \times 10^{8}(\mathrm{RPP}-8369)$

Onsite aerosol, moderate consequence SOF multiplier $=\left[\left(5.73 \times 10^{8}\right)(0.9)\right]+\left[\left(7.77 \times 10^{8}\right)(0.1)\right]$

$$
=5.93 \times 10^{8} \text {. }
$$

Onsite aerosol $\mathrm{SOF}=($ aerosol release rate) (onsite SOF multiplier) (onsite $\chi / \mathrm{Q})$

Onsite, high consequence $\mathrm{SOF}_{\text {aerosol }}=\left(1.16 \times 10^{-6} \mathrm{~m}^{3} / \mathrm{s}\right)\left(2.12 \times 10^{7}\right)\left(0.0328 \mathrm{~s} / \mathrm{m}^{3}\right)$

$$
=8.1 \times 10^{-1}
$$

Onsite, moderate consequence $\mathrm{SOF}_{\text {aerosol }}=\left(1.16 \times 10^{-6} \mathrm{~m}^{3} / \mathrm{s}\right)\left(5.93 \times 10^{8}\right)\left(0.0328 \mathrm{~s} / \mathrm{m}^{3}\right)$

$$
=2.3 \times 10^{+1}
$$

where:

$0.0328 \mathrm{~s} / \mathrm{m}^{3}=$ onsite $\chi / \mathrm{Q}(\mathrm{RPP}-13482)$.

\section{B2.1.2 Offsite Contribution of Aerosolized Waste}

Given

Offsite, high consequence SOF multiplier for bounding DST or 100-series SST liquids $=5.73 \times 10^{8}(\mathrm{RPP}-8369)$

Offsite, high consequence SOF multiplier for bounding DST or 100-series SST solids $=7.77 \times 10^{8}(\mathrm{RPP}-8369)$

Offsite aerosol, high consequence SOF multiplier $=\left[\left(5.73 \times 10^{8}\right)(0.9)\right]+\left[\left(7.77 \times 10^{8}\right)(0.1)\right]$

$$
=5.93 \times 10^{8} \text {. }
$$


And

Offsite, moderate consequence SOF multiplier for bounding DST or 100-series SST liquids $=3.71 \times 10^{9}$ (RPP-8369)

Offsite, moderate consequence SOF multiplier for bounding DST or 100-series SST solids $=2.21 \times 10^{9}(\mathrm{RPP}-8369)$

Offsite aerosol, moderate consequence SOF multiplier

$$
\begin{aligned}
& =\left[\left(3.71 \times 10^{9}\right)(0.9)\right]+\left[\left(2.21 \times 10^{9}\right)(0.1)\right] \\
& =3.56 \times 10^{9} .
\end{aligned}
$$

Offsite aerosol SOF $=($ aerosol release rate) (offsite SOF multiplier) (offsite $\chi / Q)$

Offsite, high consequence $\operatorname{SOF}_{\text {aerosol }}=\left(1.16 \times 10^{-6} \mathrm{~m}^{3} / \mathrm{s}\right)\left(5.93 \times 10^{8}\right)\left(2.22 \times 10^{-5} \mathrm{~s} / \mathrm{m}^{3}\right)$

$$
=1.5 \times 10^{-2}
$$

Offsite, moderate consequence $\mathrm{SOF}_{\text {aerosol }}=\left(1.16 \times 10^{-6} \mathrm{~m}^{3} / \mathrm{s}\right)\left(3.56 \times 10^{9}\right)\left(2.22 \times 10^{-5} \mathrm{~s} / \mathrm{m}^{3}\right)$

$$
=9.2 \times 10^{-2}
$$

where:

$2.22 \times 10^{-5} \mathrm{~s} / \mathrm{m}^{3}=$ offsite $\chi / \mathrm{Q}(\mathrm{RPP}-13482)$

\section{B2.2 CONTRIBUTION OF THE HIGH-EFFICIENCY PARTICULATE AIR FILTER}

Since the steam volume exceeds the headspace volume, it is assumed that the tank pressurizes sufficiently to fail the HEPA filters.

Onsite, bounding filter release $\mathrm{SOF}_{\mathrm{HEPA}}=5.2 \times 10^{-2}(\mathrm{RPP}-13437)$.

Offsite, bounding filter release $\mathrm{SOF}_{\mathrm{HEPA}}=7.3 \times 10^{-5}(\mathrm{RPP}-13437)$.

Since only moderate consequence SOFs were calculated in RPP-13437 for the release from a HEPA filter, these contributions will also be conservatively applied to the high consequence calculations despite over representing the contribution from the HEPA release by nearly an order of magnitude.

\section{B2.3 CONTRIBUTION FROM THE SULFURIC ACID FUMES}

The addition of sulfuric acid to the tank would also result in some quantity of sulfuric acid being present in the gas as it exits from the tank. The quantity can be estimated from the partial pressure of sulfuric acid at the conditions encountered.

Mass sulfuric acid $=(5,000 \mathrm{gal})(3.785 \mathrm{~L} / \mathrm{gal})(1.86 \mathrm{~kg} / \mathrm{L})=3.52 \times 10^{4} \mathrm{~kg}$

Mass tank waste $=(50,000 \mathrm{gal})(3.785 \mathrm{~L} / \mathrm{gal})(1.1 \mathrm{~kg} / \mathrm{L})=2.08 \times 10^{5} \mathrm{~kg}$ 
RPP-12646 REV 4

Weight percent sulfuric acid $=\left[\left(3.52 \times 10^{4} \mathrm{~kg}\right) /\left(3.52 \times 10^{4} \mathrm{~kg}+2.08 \times 10^{5} \mathrm{~kg}\right)\right] \times 100=14.5$ where:

$50,000 \mathrm{gal}=$ conservatively assumed waste volume

$1.1 \mathrm{~kg} / \mathrm{L} \quad=$ assumed density of the waste

$1.86 \mathrm{~kg} / \mathrm{L}=$ density of sulfuric acid (Weast 1981).

The vapor pressures of sulfuric acid and aqueous waste (water) at a conservative $20 \%$ sulfuric acid and $120^{\circ} \mathrm{C}$ can be found.

$$
\begin{aligned}
\text { Partial pressure of sulfuric acid }= & 4.32 \times 10^{-12} \text { bar (Perry's Chemical Engineers' } \\
& \text { Handbook }[\text { Perry 1984]) } \\
= & 4.26 \times 10^{-12} \mathrm{Atm}
\end{aligned}
$$

The total amount of sulfuric acid leaving the tank as vapor can then be found as a volumetric proportion of the total release.

$$
\begin{array}{r}
{\left[\left(9.08 \times 10^{3} \mathrm{~g} / \mathrm{s}\right) /\left(44 \mathrm{~g} / \mathrm{g} \text { mole } \mathrm{CO}_{2}\right)\right][} \\
{\left[\left(4.26 \times 10^{-12} \mathrm{Atm}\right) /(1 \mathrm{Atm})\right]} \\
=8.8 \times 10^{-10} \mathrm{~g} \text { mole } / \mathrm{s} \text { sulfuric acid vapors }
\end{array}
$$

Converting from gram moles to grams:

$$
\left(8.8 \times 10^{-10} \mathrm{~g} \text { mole } / \mathrm{s}\right)(98 \mathrm{~g} / \mathrm{g} \text { mole })=8.6 \times 10^{-8} \mathrm{~g} / \mathrm{s}
$$

\section{B2.3.1 Onsite Contribution of Sulfuric Acid}

Onsite sulfuric $\mathrm{SOF}=($ sulfuric acid release rate $)($ onsite $\chi / \mathrm{Q}) /($ sulfuric acid temporary emergency exposure limit [TEEL])

Onsite, high consequence $\mathrm{SOF}_{\text {sulfuric }}=\left(8.6 \times 10^{-8} \mathrm{~g} / \mathrm{s}\right)\left(0.0328 \mathrm{~s} / \mathrm{m}^{3}\right) /\left(3.0 \times 10^{-2} \mathrm{~g} / \mathrm{m}^{3}\right)$

$$
=9.4 \times 10^{-8}
$$

Onsite, moderate consequence SOF sulfuric $=\left(8.6 \times 10^{-8} \mathrm{~g} / \mathrm{s}\right)\left(0.0328 \mathrm{~s} / \mathrm{m}^{3}\right) /\left(1.0 \times 10^{-2} \mathrm{~g} / \mathrm{m}^{3}\right)$

$$
=2.8 \times 10^{-7}
$$

where:

$$
\begin{array}{ll}
0.0328 \mathrm{~s} / \mathrm{m}^{3} & =\text { onsite } \chi / \mathrm{Q} \text { (RPP-13482) } \\
3.0 \times 10^{-2} \mathrm{~g} / \mathrm{m}^{3} & =\text { sulfuric acid TEEL-3 (DKC-05-0002, AEGLs, ERPGs, or Rev. } 21 \\
& \text { TEELS for Chemicals of Concern 2005) } \\
1.0 \times 10^{-2} \mathrm{~g} / \mathrm{m}^{3} & =\text { sulfuric acid TEEL-2 (DKC-05-0002). }
\end{array}
$$

\section{B2.3.2 Offsite Contribution of Sulfuric Acid}

Offsite sulfuric $\mathrm{SOF}=($ sulfuric acid release rate) $($ offsite $\chi / Q) /($ sulfuric acid TEEL)

Offsite, high consequence SOF sulfuric $=\left(8.6 \times 10^{-8} \mathrm{~g} / \mathrm{s}\right)\left(2.22 \times 10^{-5} \mathrm{~s} / \mathrm{m}^{3}\right) /\left(1.0 \times 10^{-2} \mathrm{~g} / \mathrm{m}^{3}\right)$

$$
=1.9 \times 10^{-10}
$$




\section{RPP-12646 REV 4}

$\begin{aligned} \text { Offsite, moderate consequence } \mathrm{SOF}_{\text {sulfuric }} & =\left(8.6 \times 10^{-8} \mathrm{~g} / \mathrm{s}\right)\left(2.22 \times 10^{-5} \mathrm{~s} / \mathrm{m}^{3}\right) /\left(2.0 \times 10^{-3} \mathrm{~g} / \mathrm{m}^{3}\right) \\ & =9.5 \times 10^{-10}\end{aligned}$ where:

$2.22 \times 10^{-5} \mathrm{~s} / \mathrm{m}^{3} \quad=$ offsite $\chi / \mathrm{Q}$ (RPP-13482)

$1.0 \times 10^{-2} \mathrm{~g} / \mathrm{m}^{3} \quad=$ sulfuric acid TEEL-2 (DKC-05-0002)

$2.0 \times 10^{-3} \mathrm{~g} / \mathrm{m}^{3}=$ sulfuric acid TEEL-1 (DKC-05-0002).

\section{B2.4 OVERALL TOXICOLOGICAL CONSEQUENCES}

\section{B2.4.1 Total Onsite Toxicological Consequences}

Total onsite toxicological consequences $=($ aerosol contribution $)+($ HEPA contribution $)+$ (sulfuric acid contribution)

Onsite, high consequence SOF Total $_{2}=\left(8.1 \times 10^{-1}\right)+\left(5.2 \times 10^{-2}\right)+\left(9.4 \times 10^{-8}\right)$ $=8.6 \times 10^{-1}$

Onsite, moderate consequence SOF Total $=\left(2.3 \times 10^{+1}\right)+\left(5.2 \times 10^{-2}\right)+\left(2.8 \times 10^{-7}\right)$ $=2.3 \times 10^{+1}$

\section{B2.4.2 Total Offsite Toxicological Consequences}

Total offsite toxicological consequences $=($ aerosol contribution $)+($ HEPA contribution $)$ + (sulfuric acid contribution) $\begin{aligned} \text { Offsite, high consequence } \mathrm{SOF}_{\text {Total }} & =\left(1.5 \times 10^{-2}\right)+\left(7.3 \times 10^{-5}\right)+\left(1.9 \times 10^{-10}\right) \\ & =1.5 \times 10^{-2}\end{aligned}$

Offsite, moderate consequence $\mathrm{SOF}_{\text {Total }}=\left(9.2 \times 10^{-2}\right)+\left(7.3 \times 10^{-5}\right)+\left(9.5 \times 10^{-10}\right)$ $=9.2 \times 10^{-2}$.

\section{B3.0 RESULTS}

Tables B3-1 and B3-2 compare the accident consequences with the risk evaluation guidelines. Reviewing the consequences shows that the mixing of incompatible materials accident is above the onsite moderate radiological guidelines. Offsite toxicological consequences are below the guidelines. However, the toxicological release exceeds the onsite moderate toxicological guidelines. 
Table B3-1. Summary of Onsite Radiological Consequences Without Controls for the Mixing of Incompatible Materials.

\begin{tabular}{|c|c|c|c|}
\hline \multirow{2}{*}{ Case } & \multicolumn{2}{|c|}{ Onsite Radiological Consequences } \\
\cline { 2 - 4 } & $\begin{array}{c}\text { Calculated dose } \\
\text { (rem) }\end{array}$ & $\begin{array}{c}\text { Moderate } \\
\text { consequence } \\
\text { guideline } \\
\text { (rem) }\end{array}$ & $\begin{array}{c}\text { High consequence } \\
\text { guideline } \\
\text { (rem) }\end{array}$ \\
\hline Mixing of incompatible materials & $4.3 \times 10^{+1}$ & $2.5 \times 10^{+1}$ & $1.0 \times 10^{+2}$ \\
\hline
\end{tabular}

Table B3-2. Summary of Toxicological Consequences Without Controls for the Mixing of Incompatible Materials.

\begin{tabular}{|c|c|c|c|c|c|c|c|c|}
\hline \multirow{4}{*}{ Case } & \multicolumn{8}{|c|}{ Toxicological Consequences } \\
\hline & \multicolumn{4}{|c|}{ Onsite } & \multicolumn{4}{|c|}{ Offsite } \\
\hline & \multicolumn{2}{|c|}{$\begin{array}{c}\text { Moderate } \\
\text { consequence }\end{array}$} & \multicolumn{2}{|c|}{ High consequence } & \multicolumn{2}{|c|}{$\begin{array}{c}\text { Moderate } \\
\text { consequence }\end{array}$} & \multicolumn{2}{|c|}{ High consequence } \\
\hline & SOF & Guideline & SOF & Guideline & SOF & Guideline & SOF & Guideline \\
\hline $\begin{array}{l}\text { Mixing of } \\
\text { incompatible } \\
\text { materials }\end{array}$ & $2.3 \times 10^{+1}$ & 1 & $8.6 \times 10^{-1}$ & 1 & $9.2 \times 10^{-2}$ & 1 & $1.5 \times 10^{-2}$ & 1 \\
\hline
\end{tabular}

Note:

SOF $=$ sum of fractions.

\section{B4.0 REFERENCES}

DKC-05-0002, 2005, AEGLs, ERPGs, or Rev. 21 TEELs for Chemicals of Concern 2005, U.S. Department of Energy, Washington, D.C.

DOE-HDBK-3010-94, 2000, Airborne Release Fractions/Rates and Respirable Fractions for Nonreactor Nuclear Facilities, Change Notice No. 1, U.S. Department of Energy, Washington, D.C.

HNF-4240, 2000, Organic Solvent Topical Report, Rev. 1, CH2M HILL Hanford Group, Inc., Richland, Washington.

Perry, R. H., 1984, Perry's Chemical Engineers' Handbook, 6th Edition, R. H. Green and D. W. Green, editors, McGraw-Hill, Inc., New York, New York.

RPP-5924, 2003, Radiological Source Terms for Tank Farms Safety Analysis, Rev. 3, CH2M HILL Hanford Group, Inc., Richland, Washington. 
RPP-8369, 2003, Chemical Source Terms for Tank Farms Safety Analyses, Rev. 2, CH2M HILL Hanford Group, Inc., Richland Washington.

RPP-9689, 2006, Offsite Radiological Consequence Calculation for the Bounding Mixing of Incompatible Materials Accident, Rev. 4, CH2M HILL Hanford Group, Inc., Richland, Washington.

RPP-13437, 2005, Technical Basis Document for Ventilation System Filtration Failures Leading to Unfiltered Release, Rev. 1, CH2M HILL Hanford Group, Inc., Richland, Washington.

RPP-13482, 2003, Atmospheric Dispersion Coefficients and Radiological/Toxicological Exposure Methodology for Use in Tank Farms, Rev. 2, CH2M HILL Hanford Group, Inc., Richland, Washington.

RPP-14442, 2003, Calculation of Acid Flow Rates into DSTs, Rev. 0, CH2M HILL Hanford Group, Inc., Richland, Washington.

Weast, R. C., 1981, CRC Handbook of Chemistry and Physics, $61^{\text {st }}$ Ed., CRC Press, Inc., Boca Raton, Florida.

WHC-SD-TWR-RPT-003, 1996, DELPHI Expert Panel Evaluation of Hanford High Level Waste Tank Failure Modes and Release Quantities, Rev. 0, Westinghouse Hanford Company, Richland, Washington. 


\section{RPP-12646 REV 4}

This page intentionally left blank.

B-12 
RPP-12646 REV 4

\section{APPENDIX C}

MIXING OF INCOMPATIBLE MATERIALS

CONTROL DECISION MEETING ATTENDEES

C-i 


\section{RPP-12646 REV 4}

This page intentionally left blank.

C-ii 


\title{
APPENDIX C \\ MIXING OF INCOMPATIBLE MATERIALS CONTROL DECISION MEETING ATTENDEES
}

\begin{abstract}
MIXING OF INCOMPATIBLE MATERIALS CONTROL DECISION MEETING ATTENDANCE SEPTEMBER 16, 2002
\end{abstract}

\begin{tabular}{|c|c|c|c|}
\hline Name & $\begin{array}{c}\text { Kuowledge Aren(s) } \\
\text { Represenled (sec bclow) }\end{array}$ & Organization & $\begin{array}{c}\text { Telephone } \\
\text { Number }\end{array}$ \\
\hline 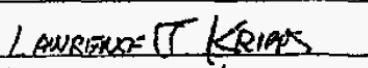 & $1,2,3,2,7,9,10$ & NSUL - CNG & $376 \cdot 1061$ \\
\hline Kevin Sandger & $1,2,3,6,9,10$ & NISPL $-C H E$ & 372.0371 \\
\hline Josepht Bevelntont & $1-23$ & OR6 & $376-8 \times 43$ \\
\hline$d_{O_{1}} \subset$ GEISBOSH & & $C H G / A R$ & $373-0486$ \\
\hline CLAF Afterpion & & CAC OAS & 3220566 \\
\hline 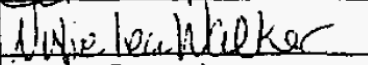 & 123410 & NSGiL DSA & 373.9045 \\
\hline Jennifer Stewart & $1,7,9$ & & \\
\hline Ed Ford & $1,2,3,6,7,9,10$ & aS $\{L-C H G$ & $373-1296$ \\
\hline MultoN V Sbultz & $1,2,3,6,7,9,10$ & NS $: C-C H E$ & $3>2-3>40$ \\
\hline Tin inpuzzan & $1,2,3,4,5,4,16$ & & \\
\hline Mark Siuduson & & DNSSSB & $373-010 i$ \\
\hline Lant Reiclmats & 5 & SST & 6.4796 \\
\hline Band Smunt & & CHG NStL & 3761907 \\
\hline & & & \\
\hline & & & \\
\hline & & & \\
\hline & & & \\
\hline & & & \\
\hline & & & \\
\hline & & . & \\
\hline
\end{tabular}

Kum licdge Arcis:

1 Licensing

2 Satily Analysis

Hazard Analysis

+ Enginecring

Ophrations

Actident Antalysis

7 Nucleatr Satlity

8 Design Authority
9 Techutical Silleţ Requiruments

II Solety Strtcilures. Syskems, and Components

11 Enkergency Prepirediness

12 Ratiutsugicul Control

1.3 Keguliton Compliantu

14 Envirenmental ]'ratestion

15 Quality Assurance

16 Other-specify
17 Industrial Safety

Is Projet Manageturent

19) Industrial Hygiture

21) M:sintcn:tlee Enginetring

21 Reliathility Enginecring

22 Jresss: Enginerius

23 Equipuent Engineering 
MIXING OF INCOMPATIBLE MATERIALS CONTROL DECISION MEETING ATTENDANCE SEPTEMBER 16, 2002

\begin{tabular}{|c|c|c|c|}
\hline Name & $\begin{array}{c}\text { Knowledge Aren(s) } \\
\text { Represented (sce below) }\end{array}$ & Organization & $\begin{array}{l}\text { Telephone } \\
\text { Number }\end{array}$ \\
\hline Don Quilici & 19 & EWds & 6.6549 \\
\hline Robn Forq & 19 & Feter & $3-0<30$ \\
\hline$B C w_{1 \times T}$ & 5 & $\mathrm{CHG}$ & $3-3355$ \\
\hline$Y \because A$ Whites & 5 & $\mathrm{CHC}$ & $3-3355$ \\
\hline S.D. Fowler & $16-C_{\text {rit }}$ SAFEty, ZZ & $\mathrm{CHG}$ & $3-59.36$ \\
\hline RDCarvell & 2367910 & ORe sunt & $947-6421$ \\
\hline Tm Blad & 4 & $5 \times 52 \pi$ & $373-3880$ \\
\hline & & & \\
\hline & & & \\
\hline & & & \\
\hline & & & \\
\hline & & & \\
\hline & & & \\
\hline & & & \\
\hline & & & \\
\hline & & & \\
\hline & & & . \\
\hline & & & \\
\hline & & & \\
\hline & & & \\
\hline
\end{tabular}

Kinuvledge Are:ıs:

1 Licensing

2 Sarety Aualysis

Hazand Analysi

Engimering

Operstions:

Aceident Analysis

Nuclear Salety

[xesiges Authority
9 Teelunical Salety Reguiroments.

(1) Satein Structures. Systems, and Compenents

11 Emergenes Prepartiduess

12 Rndiological Conterol

1.3 Rezulaliny Compliance

If En iromintintal Prutection

15 Qualiny Assusubce

16 Oluer-spresity
17 Jndustrial Satieny

18 Iroject Mantagentent

19) Intustrial Hygienc

21) Mtaintenante Enginecring

21 Ketinbility-Engineering

22 Irecess Enginetring

2.3 Equipunent Engineering 


\section{RPP-12646 REV 4}

\section{MIXING OF INCOMPATIBLE MATERIALS CONTROL DECISION MEETING ATTENDANCE AUGUST 23, 2002}

\begin{tabular}{|c|c|c|c|}
\hline Name & $\begin{array}{l}\text { Knowledge Area(s) } \\
\text { Represented (see below) }\end{array}$ & Organization & $\begin{array}{l}\text { Telephone } \\
\text { Number }\end{array}$ \\
\hline 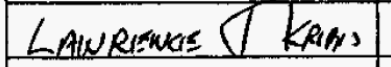 & $2,3,9,16$ & NSK & $376-k 61$ \\
\hline Kevin Sandgren & $1,2,3,6,9$ & NS\&L & $372-0374$ \\
\hline Bobby Meduriet & $2,5,5,9$ & ops & $373 \cdot 1450$ \\
\hline CHUNN MALCOM & 5 & DPS & 373.2525 \\
\hline Johnston, Julie & 5 & CPO & $3-3578$ \\
\hline HAr Ptop, curfond & $2,3,5,2,13$ & 965 & $2-0526$ \\
\hline Boh (larrell & 262910 & ORP-support & $501-6421$ \\
\hline Brad Evans & $1-3,6,7,9,10$ & & \\
\hline Mlctaw SHULTZ & $2,3,6,7,9,10$ & $C H+C-N S B L$ & $322-3740$ \\
\hline Ed Ford & $2,3,2,79,10$ & CNG-aSEL & $373-1296$ \\
\hline Mark Sautmen & & DNFSB & $373-0$ i.oi \\
\hline KENNY FOULLER & $4,27,16-C_{\text {nit }}$ SAEty & CHK Prec Enge & $373-5930$ \\
\hline Qivey Jones & $1,2,3,5,7,9,10$ & oss & $373-5717$ \\
\hline & & & \\
\hline & & & \\
\hline & & & \\
\hline & & & \\
\hline & & & \\
\hline & & & \\
\hline & & & \\
\hline
\end{tabular}

Knowledge Areas:

2 Sntety Anatysis

Hazard Analysis

Engineering

Operations

Accident Analysis

Nuclear Sufety

Design Authority
9 Technical Sately Requirements

10 Safety Structures, Systems. snd Components

1) Emergency Preparedness

12 Radiological Control

13 Regulatory Compliance

14 Environmental Frotection

15 Quality Assurance

16 Other - spevify
17 Industrial Safety

18 Project Management

19 Industrial Hygiene

21) Maintenance Enginetring

21 Reliability Engineering

22 Protess Enginetring

23. Equipment Engineering 


\section{RPP-12646 REV 4}

MIXING OF INCOMPATIBLE MATERIALS CONTROL DECISION MEE'TING ATTENDANCE AUGUST 23, 2002

\begin{tabular}{|c|c|c|c|}
\hline Name & $\begin{array}{c}\text { Knowledge Area(s) } \\
\text { Represented (see below) }\end{array}$ & Organization & $\begin{array}{c}\text { Telephone } \\
\text { Number }\end{array}$ \\
\hline$D_{2 N} Q_{u i}^{\prime}{ }_{\text {li }}$ & 171.19 & $\varepsilon \forall \sigma s$ & $6-6549$ \\
\hline TODD Blenk & 4 & DST SYS Eug & 3.3880 \\
\hline w.I Prurell & 4 & Descain Eua & $373-1072$ \\
\hline M.A.F-\&U. & 4 & Dosyineni & $372-3657$ \\
\hline J.L. stewart & $1,7,9$ & $N S+L$ & $376-5633$ \\
\hline LTON SPARles & & QA & $372-1749$ \\
\hline Leais Karo & $1,2^{3}, 1,7$ Ceserise & & \\
\hline Eustol. Soumes $\alpha$ & 5 & EASTTROUK FRRE & $323.3^{3475}$ \\
\hline Whielen Walkel & 12347910 & NSAL & $373-13 \times 2$ \\
\hline Tim Trapazzano & $1,2,3,4,5,7,9,10$ & NS3L & $873-1342$ \\
\hline Cuat Reíchmoth & 5 & SST OP & 64796 \\
\hline & & & \\
\hline & & & \\
\hline & & & \\
\hline & & & \\
\hline & & & \\
\hline & & & \\
\hline & & & \\
\hline & & & \\
\hline & & & \\
\hline
\end{tabular}

Knowledge Areas:

Licensing

Satety Analysis

Hazard Analysis

Engineering

Operations

Accident Assalysis

Nuclear Salety

Design Authority
9 Technical Satety Requirements.

10 Safety Structures, Systems, and Components

11 Energency Proparedness

12 Radiologital Control

13 Regulatory Compliance

14 Environmental Protection

15 Quality Assurance

16 Other-specify
17 Industrial Satety

18 Project Managernent

19 Industrial Hygiene

20 Maintenance Engineering

21 Reliahility Engineering

22 Process Engineering

23 Equipment Engineering 
RPP-12646 REV 4

\section{APPENDIX D}

PEER REVIEW CHECKLIST

D-i 
RPP-12646 REV 4

This page intentionally left blank.

D-ii 


\title{
APPENDIX D \\ PEER REVIEW CHECKLIST
}

CHECKLIST FOR TECHNICAL PEER REVIEW

Page 1 of 2

Document Reviewed: ECN 723852 R0 (RPP-12646, Mixing of Incompatible Materials in Waste Tanks Technical Basis Document, Revision 4)

Scope of Review (e.g., document section or portion of calculation): Changes from Revision 3 to Revision 4.

\author{
$\underline{\text { Yes } \mathrm{No}^{*} \mathrm{NA}^{*}}$ \\ $\bigotimes \square \square$ 1. Previous reviews are complete and cover the analysis, up to the scope of this \\ review, with no gaps. 'Explanation: \\ $\bigotimes \square \square \quad$ 2. Problem is completely defined. *Explanarion: \\ $\bigotimes \square \square \quad 3$. Accident scenarios are developed in a clear and logical manner \\ "Explanation: \\ $\triangle \square \square \quad$ 4. Analytical and technical approaches and results are reasonable and appropriate. \\ (ORP QAPP criterion 2.8) +Explanation: \\ $\bigotimes \square \square \quad 5$. Necessary assumptions are reasonable, explicitly stated, and supported. (ORP \\ $Q A P P$ criterion 2.2) *xplanation: \\ 6. Computer codes and data files are documented. \\ "Explanation: No computer condes were used. \\ 7. Data used in calculations are explicitly stated. \\ *Explanation: \\ 8. Bases for calculations, including assumptions and data, are consistent with the \\ supported safety basis document (e.g., the Tank Farms Documented Safety \\ Analysis). ‘Explanation: \\ $\bigotimes \square \square$ 9. Data were checked for consistency with original source information as applicable. \\ (ORP QAPP criterion 2.9) *Explanation: \\ $\otimes \square \square \quad 10$. For both qualitative and quantitative data, uncertainties are recognized and \\ discussed, as appropriate. (ORP QAPP criterion 2.17) \\ "Explanation: \\ $\triangle \square \square \quad$ 11. Mathematical derivations were checked including dimensional consistency of \\ results. (ORP QAPP criterion 2.16) \\ "Explanation: \\ $\otimes \quad$ 12. Models are appropriate and were used within their established range of validity or \\ adequate justification was provided for use outside their established range of \\ validity. "Explanation: No models were used. \\ $\bigotimes \square \square \quad$ 13. Spreadsheet results and all hand calculations were verified. \\ *Explanation: \\ $\triangle \square \square \quad$ 14. Calculations are sufficiently detailed such that a technically qualified person can \\ understand the analysis without requiring outside information. (ORP QAPP \\ criterion 2.5) *Explanation: \\ $\square \square \square \quad \begin{aligned} & \text { 15. Software input is correct and consistent with the document reviewed. } \\ & \text { *Explanation: No software was used. }\end{aligned}$
$\square \square \bigotimes \quad$ 15. Software input is correct and consistent with the document reviewed.
$\square \square \square$ 16. Software output is consistent with the input and with the results reported in the \\ document reviewed. "Explanation: No sofiware was used. \\ $\triangle \quad$ 17. Software verification and validation are addressed adequately. (ORP QAPP \\ criterion 2.6) "Explanation: No sofiware was used. \\ $\otimes \square \square \quad$ 18. Limits/criteria/guidelines applied to the analysis results are appropriate and \\ referenced. Limits/criteria/guidelines were checked against references. (ORP \\ $Q A P P$ criterion 2.9) *Explanation: \\ $\bigotimes \square \square \quad$ 19. Safety margins are consistent with good engineering practices. \\ Explanation: \\ $\otimes \square \square \quad 20$. Conclusions are consistent with analytical results and applicable limits.
}




\section{RPP-12646 REV 4}

\section{CHECKLIST FOR TECHNICAL PEER REVIEW}

Page 2 of 2

Yes No"NA*

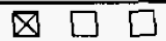

区

21. Results and conclusions address all points in the purpose.

(ORP QAPP criterion

2.3) *Explanation:

22. All references cited in the text, figures, and tables are contained in the reference list. "Explanation: $\square \square \quad$ 23. Reference citations (e.g., title and number) are consistent between the text callout
and the reference list. Explanation:

$\bigotimes \square \square \quad 24$. Only released (i.e., not draft) references are cited. (ORP QAPP criterion 2.1) "Explanation:

$\nabla \square \square \quad 25$. Referenced documents are retrievable or otherwise available. Explanation:

$\nabla \square$ 26. The most criterion 2.1) Explanation:

$\bigotimes \square \square \quad 27$. There are no duplicate citations in the reference list. Explanation: $\bigotimes \square \square \quad \begin{aligned} & \text { 28. Referenced documents are spelled out (title and number) the first time they are } \\ & \text { cited. 'Explanation: }\end{aligned}$

Q $\square \square \quad 29$. All acronyms are spelled out the first time they are used.

Explanation:

$凶 \square \square$ 30. The Table of Contents is correct. *Explanation:

$\square \square \square \quad 31$. All figure, table, and section callouts are correct. Explanation:

$\bigotimes \square \square$ 32. Unit conversions are correct and consistent.

Explanation:

$\otimes \square \square \quad 33$. The number of significant digits is appropriate and consistent. -Explanation:

$\bigotimes \square \square \quad$ 34. Chemical reactions are correct and balanced. *Explanation: No chemical reacrions were used

$\triangle \square \square \quad 35$. All tables are formatted consistently and are free of blank cells. Exptanation: No changes to tables were made.

$\otimes \square \square \quad 36$. The document is complete (pages, attachments, and appendices) and in the proper order. *Explanation:

$\otimes \square \square \quad 37$. The document is free of typographical errors. Only the section(s) being reviewed was checked for typographical errors. "Explanation:

$\otimes \square \square \quad 38$. The tables are internally consistent. *Explanation:

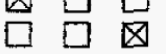

39. The document was prepared in accordance with HNF-2353, Section 4.3, Attachment B, "Calculation Note Format and Preparation Instructions." "Explanation: This was a change to an existing document and was not a change to a calculation nose.

$\otimes \square \square$ 40. Impacted documents are appropriately identified in Blocks 7 and 24 of the Engineering Change Notice (form A-6003-563.1). *Explanation:

$\triangle \square \square$ 41. If more than one Technical Peer Reviewer was designated for this document, an overall review of the entire document was performed after resolution of all Technical Peer Review comments and confirmed that the document is selfconsistent and complete. *Explanation:

\section{$\otimes \square \square$ Concurrence}

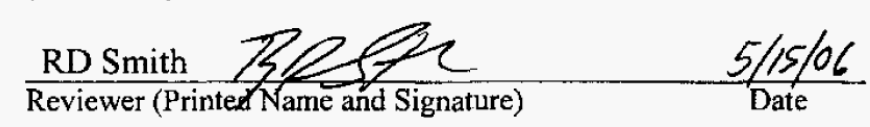

* If No or NA is chosen, an explanation must be provided on this form. Additional explanation: 


\section{CHECKLIST FOR TECHNICAL PEER REVIEW}

Document Reviewed: RPP-12646, Mixing of Incompatible Materials in Waste Tanks Technical Basis Document, Rev. 4

Scope of Review (e.g., document section or portion of calculation): Technical edit

Yes No $\mathrm{NA}^{*}$

[] [ ] [x] 1. Previous reviews are complete and cover the analysis, up to the scope of this review, with no gaps.

[] [1] [x] 2. Problem is completely defined.

[1] [ ] [x] 3. Accident scenarios are developed in a clear and logical manner.

[] [ ] [x] 4. Analytical and technical approaches and results are reasonable and appropriate. (ORP QAPP criterion 2.8)

[] [ ] [x] 5. Necessary assumptions are reasonable, explicitly stated, and supported. (ORP QAPP criterion 2.2)

[] [ ] [x] 6. Computer codes and data files are documented.

[] [] [x] 7. Data used in calculations are explicitly stated.

[] [ ] [x] 8. Bases for calculations, including assumptions and data, are consistent with the supported safety basis document (e.g., the Tank Farms Final Safety Analysis Report).

[] [] [x] 9. Data were checked for consistency with original source information as applicable. (ORP QAPP criterion 2.9)

[] [ ] [x] 10. For both qualitative and quantitative data, uncertainties are recognized and discussed, as appropriate. (ORP QAPP criterion 2.17)

[ ] [ ] [x] 11. Mathematical derivations were checked including dimensional consistency of results. (ORP QAPP criterion 2.16)

[ ] [ ] [x] 12. Models are appropriate and were used within their established range of validity or adequate justification was provided for use outside their established range of validity.

[ ] [ ] [x] 13. Spreadsheet results and all hand calculations were verified.

[] [ ] [x] 14. Calculations are sufficiently detailed such that a technically qualified person can understand the analysis without requiring outside information. (ORP $Q A P P$ criterion 2.5)

[ ] [ ] [x] 15. Software input is correct and consistent with the document reviewed.

[ ] [ ] [x] 16. Software output is consistent with the input and with the results reported in the document reviewed.

[ ] [ ] [x] 17. Software verification and validation are addressed adequately. (ORP QAPP criterion 2.6)

[ ] [ ] [x] 18. Limits/criteria/guidelines applied to the analysis results are appropriate and referenced. Limits/criteria/guidelines were checked against references. (ORP QAPP criterion 2.9)

[ ] [ ] [x] 19. Safety margins are consistent with good engineering practices.

[] [] [x] 20. Conclusions are consistent with analytical results and applicable limits

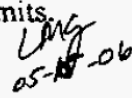




\section{RPP-12646 REV 4}

\section{CHECKLIST FOR TECHNICAL PEER REVIEW}

[ ] [] [x] 21. Results and conclusions address all points in the purpose. (ORP QAPP criterion 2.3)

[x] [ ] [ ] 22. All references cited in the text, figures, and tables are contained in the reference list.

[x] [ ] [ ] 23. Reference citations (e.g., title and number) are consistent between the text callout and the reference list.

[x] [ ] [ ] 24. Only released (i.e., not draft) references are cited. (ORP QAPP criterion 2.1)

[x] [ ] [] 25. Referenced documents are retrievable or otherwise available.

[x] [] [ ] 26. The most recent version of each reference is cited, as appropriate. (ORP QAPP criterion 2.1)

[x] [ ] [ ] 27. There are no duplicate citations in the reference list.

[x] [ ] [] 28. Referenced documents are spelled out (title and number) the first time they are cited.

[x] [ ] [ ] 29. All acronyms are spelled out the first time they are used.

[x] [ ] [ ] 30. The Table of Contents is correct.

[x] [ ] [ ] 31. All figure, table, and section callouts are correct.

[x] [] [] 32. Unit conversions are correct and consistent.

[x] [] [] 33. The number of significant digits is appropriate and consistent.

[] [ ] [ $\mathrm{x}$ ] 34, Chemical reactions are correct and balanced.

[x] [ ] [ ] 35. All tables are formatted consistently and are free of blank cells.

[x] [ ] [ ] 36. The document is complete (pages, attachments, and appendices) and in the proper order.

[x] [] [] 37. The document is free of typographical errors.

[x] [ ] [ ] 38. The tables are internally consistent.

[x] [ ] [ ] 39. The document was prepared in accordance with HNF-2353, Section 4.3, Attachment B, "Calculation Note Format and Preparation Instructions".

[] [ ] [x] 40. Impacted documents are appropriately identified in Blocks 7 and 24 of the Engineering Change Notice (form A-6003-563.1).

[x] [] [] 41. If more than one Technical Peer Reviewer was designated for this document, an overall review of the entire document was performed after resolution of all Technical Peer Review comments and confirmed that the document is selfconsistent and complete.

\section{[x] [1] [I Concurrence}

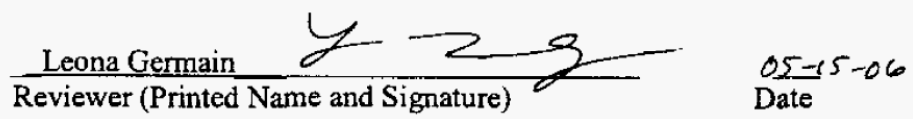

* If No or NA is chosen, provide an explanation on this form.

Technical Edit 